\title{
DIFFERENCES IN NITROGEN AND PHOSPHORUS UPTAKE AND YIELD COMPONENTS BETWEEN BARLEY CULTIVARS GROWN UNDER ARBUSCULAR MYCORRHIZAL FUNGUS AND PSEUDOMONAS STRAINS CO-INOCULATION IN RAINFED CONDITION
}

\author{
ESPIDKAR, Z. ${ }^{1}$ - YARNIA, M. ${ }^{1 *}$ - ANSARI, M. H. ${ }^{2}$ - MIRSHEKARI, B. ${ }^{1}$ - ASADI RAHMANI, H. ${ }^{3}$ \\ ${ }^{1}$ Department of Agronomy and Plant Breeding, Tabriz Branch, \\ Islamic Azad University, Tabriz, Iran \\ ${ }^{2}$ Department of Agronomy and Plant Breeding, Rasht Branch, \\ Islamic Azad University, Rasht, Iran \\ ${ }^{3}$ Soil and Water Research Institute, Agricultural Research, \\ Education and Extension Organization, Karaj, Iran \\ *Corresponding author \\ e-mail:m.yarnia@yahoo.com \\ phone: +98-914-116-7065 \\ (Received $8^{\text {th }}$ Mar 2017; accepted $6^{\text {th }}$ Jun 2017)
}

\begin{abstract}
Drought is a major limiting factor of plant production in arid and semi-arid regions including Iran. The use of arbuscular mycorrhizal fungi and plant growth promoting rhizobacteria (PGPR) may constitute a biological alternative to increase crop yield and plant resistance in water stress conditions. In order to evaluate the synergistic effect of four strains of Pseudomonas and arbuscular mycorrhizal fungi (AMF) on nitrogen and phosphorus uptake and yield components of Iranian barley cultivars (Dasht and Sahra) under rain-fed conditions, a two-year experiment was conducted in factorial randomized complete block design. The results demonstrated that in most of the characteristics, the interaction effect of Pseudomonas $\times$ AMF on cultivars in both years was significant. While Pseudomonas strains exhibited different reactions to cultivar and AMF use, in most of the traits measured, they were superior when compared to control. In both cultivars, the maximum yield parameters studied was obtained from coinoculation of AMF + S4 strain. The Sahra has more production sustainability in comparison to Dasht (seed yield of Dasht 1293 and $1912 \mathrm{~kg} / \mathrm{ha}$; Sahra 1752 and $1939 \mathrm{~kg} / \mathrm{ha}$ in first and second year, respectively). Moreover, in both years and in both cultivars, the co-inoculation increased $\mathrm{P}$ and $\mathrm{N}$ concentration and uptake significantly. It increased seed yield, while the yield increase was more evident in the Sahra. According to the results obtained, to achieve the maximum seed yield in rain-fed conditions of Iran, cultivation of Sahra alongside co-inoculation of AMF + Pseudomonas putida S4 strain is recommended.
\end{abstract}

Keywords: Glamus intraradices; $N$ concentration; $P$ concentration; seed yield

\section{Introduction}

Drought is one of the most serious problems in the Middle East, especially in arid and semiarid countries (Kheiri et al., 2017). Considering population growth rates and limited global water resources, it is anticipated that food security will become a serious challenge in the coming decades (Sheffield et al., 2012). The agricultural sector in Iran is one of the most important economic sectors of the country, and water is the most limiting factor for production (Schoppach et al., 2017). Whereas around 92\% of agro products depend on water, less than one-third of the cultivated area is irrigated; the rest is devoted to dry farming (FAO, 2014). In these areas, barley (Hordeum vulgare L.) is 
grown mainly under rainfed conditions and could fall victim to drought at any stage of growth (Dijkman et al., 2017; Schoppach et al., 2017).

Extensive research is being carried out throughout the world to develop strategies to cope with drought stress by developing drought tolerant cultivars (Oukarroum et al., 2009), shifting crop calendars (Lu et al., 2017), and optimizing fertilizer use (Cetin and Akinci, 2015), agronomic practices (Mupangwa et al., 2012) and resource management practices (Parry et al., 2005; Habiba et al., 2012). Most of these technologies are costintensive. Non-normative and long-term use of chemical fertilizers gradually decreases soil quality, reduces the quality of the product, causes imbalances in the natural ecosystems and extends environmental pollution (Ali et al., 2005; Vurukonda et al., 2016).

As a relatively simple and low-cost alternative strategy, the use of free-living plant growth-promoting rhizobacteria (PGPR) is a promising broad-spectrum means of improving plant growth (Yang et al., 2009). The use of microorganisms, especially for intensive culture and in nutrient-poor soil, is essential to preserving the quality of the soil in Iran (Arzanesh et al., 2011). Recent studies in Iran indicate that microorganisms can also help plants to cope with drought stress (Tabatabaei et al., 2016; Khalilzadeh et al., 2016; Delshadi et al., 2017). These bacteria contribute to plant growth by fixing free-living nitrogen, producing growth metabolites such as plant hormones, increasing the solubility of insoluble compounds such as $\mathrm{P}$ and $\mathrm{K}$ by producing mineral and organic acids and by siderophore production. This increases the supply of micronutrients, especially iron, and reduces the negative effects of stress ethylene and the production of amino cyclopropane-1-carboxylate (ACC) (Arshad et al., 2008). A large number of PGPRs hydrolyze ACC to ammonia, ethylene and alpha ketobutyrate to prevent overproduction of stress ethylene in plants and reduce root growth by producing ACC deaminase enzyme (Glick, 2014).

Pseudomonas fluorescent has been investigated because of its catabolic versatility, excellent colonization ability at the root surface and the ability to produce a wide range of enzymes and metabolites that may be useful in a variety of biotic and abiotic stresses (Mayak et al., 2004). Pseudomonas is an important ACC deaminase enzyme-producing bacteria (Glick, 2014). In many arid regions of the world and in Iran, it reduces the negative effects caused by stress tests. Arshad et al. (2008) demonstrated that inoculation of wheat (Triticum aestivum) with Pseudomonas putida under drought stress improved water status and an additional elastic adjustment that increased grain yield and mineral quality (Mg, K, and Ca). Frohlich et al. (2012) carried out greenhouse and field experiments and reported that Pseudomonas sp. DSMZ 13134-treated barley showed increased yield and straw weight under nutrient deprivation. Plants treated with exopolysaccharide (EPS) producing bacteria displayed increased resistance to water stress (Bensalim et al., 1998).

The EPS-producing strain of Pseudomonas putida GAP-P45 formed a biofilm on the root surface of sunflower seedlings and imparted tolerance to plants against drought stress (Sandhya et al., 2009). The inoculated seedlings showed improved soil aggregation and root-adhering soil and higher relative water content (RWC) in the leaves. Inoculation of two different crops (tomatoes and peppers) with PGPR Pseudomonas putida KT2440 augmented the antioxidant catalase under severe drought conditions, suggesting that trehalose produced by these microorganisms correlates with their ability to protect plants against drought (Vílchez et al., 2016). 
Arbuscular mycorrhiza fungi (AMF) form beneficial symbiotic associations with most plants and play a vital role in plant growth under various conditions by modifying the root system and enhancing the mobilization and uptake of several essential elements. They have also been reported to stimulate plant stress tolerance by enhancing enzymatic as well as non-enzymatic antioxidant defense systems (Wu et al., 2014; Ahmad et al., 2014), lipid peroxidation (Abd_Allah et al., 2015), and phytohormone synthesis (Navarro et al., 2013).

Researchers have stated that some Pseudomonas strains can have stimulatory effects on AM growth under drought stress (Meyer and Linderman, 1986). One study found that severe colonization of barley roots by AMF increases plant growth and dry matter production (Chaurasia and Khare, 2005). AMF helper bacteria colonization such as Pseudomonas stick to root surfaces and reform the symbiotic relationship between AMF and the plant to provide many benefits to the host plant (Schalamuk et al., 2006). AMF helper bacteria offer mechanisms that affect the deployment and performance of AMF symbiosis and stimulates spore germination, fungal contact with roots or prompt AMF root production (Frey-Klett et al., 2007; Parmar and Dufresne, 2011; Nadeem et al., 2014).

These findings indicate that the co-inoculation of AM and Pseudomonas can enhance the activity of AM during symbiosis with the host plant (Artursson et al. 2006). Barea et al. (2005) concluded that the cooperation of Pseudomonas and AM in nutrient uptake by plants is probably due to specific attributes of the microorganisms and there is a growing interest in improving understanding of their involvement in nutrient cycling and non-nutritional physiological values that make the plant more tolerant of drought stress.

There have been no investigations thus far into the synergistic effect of root colonization of fluorescent Pseudomonads and AMF on barley under dry land farming conditions in Iran. In many crops, root colonization by fluorescent Pseudomonads and AMF changes a plant's nutrient uptake, growth and drought resistance. The present study focused on the agronomic effects of native Pseudomonas strains and AMF on $\mathrm{N}$ and $\mathrm{P}$ uptake and yield in barley. The hypothesis tested was that the co-inoculation of Pseudomonas strains and AMF would increase the nutrient uptake and yield of barley cultivars and would induce resistance against water deficit.

\section{Materials and methods}

\section{The study site}

A field experiment was carried out in Research Center of Ardebil Islamic Azad University with a height of 1460 meters above sea level, longitude $48^{\circ} 20^{\prime}$ and latitude of $38^{\circ} 19^{\prime}$ under rain-fed conditions during both 2014-2015 and 2015-2016 growing seasons. Climatic condition of Ardebil province is characterized by a semi-arid climate (humid winters and dry summers). Rainfall distribution is fluctuate in Ardebil province and most of precipitation occurs between October and May, and precipitation of long term is $424 \mathrm{~mm}$. Annual rainfall were 348 and $407 \mathrm{~mm}$ during 2014-2015 and 20152016 growing seasons respectively in Ardebil. Mean monthly rainfall (Figure 1) and monthly temperature (Figure 2) during plant growth for both years have been presented. Soil samples were collected from the surface (0-30 and 30-60 $\mathrm{cm}$ depth) before sowing. Samples were air dried and powdered with wooden mortar and pestle and passed through a $2 \mathrm{~mm}$ stainless steel sieve. Soil experiment results are presented in Table 1. 


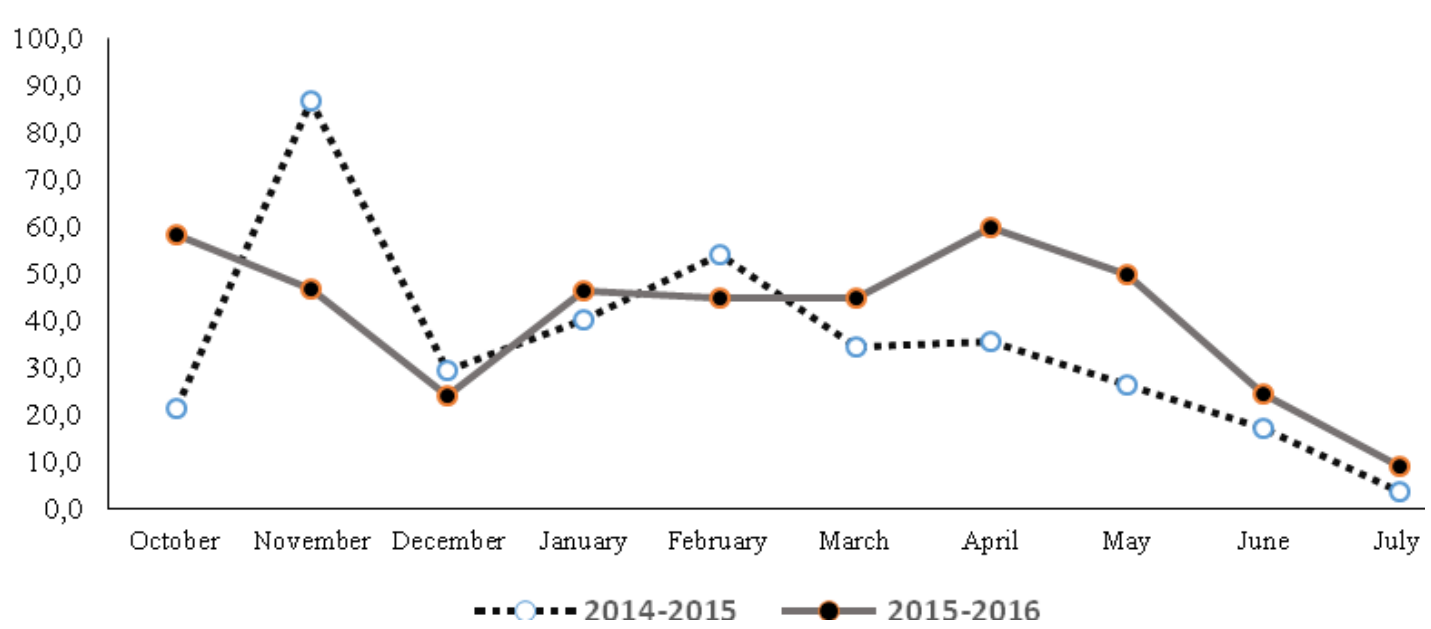

Figure 1. Mean monthly rainfall during the growth period of plant (Source: Weather Station at Experimental Farm of Azad University of Ardabil)

Mean monthly rainfall during plant growth $\left({ }^{\circ} \mathrm{C}\right)$

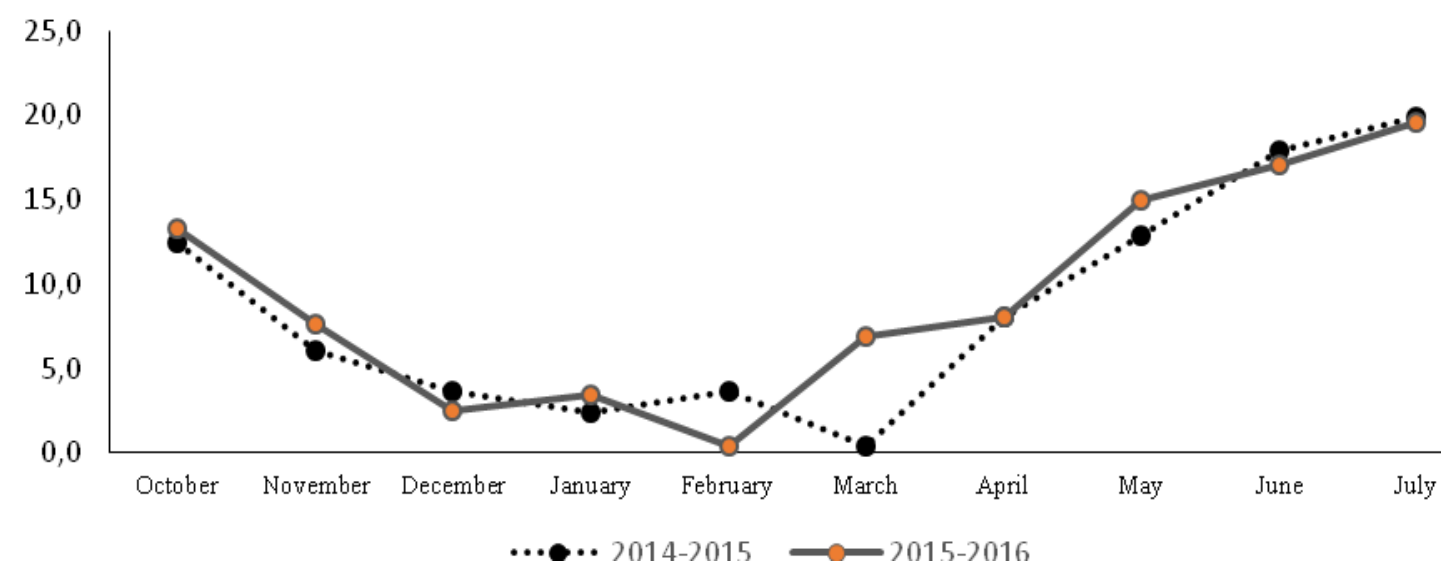

Figure 2. Mean monthly temperature during the growth period of plant (Source: Weather Station at Experimental Farm of Azad University of Ardabil)

Table 1. Soil Physical and chemical characteristics of the soil during the two-year study

\begin{tabular}{|c|c|c|c|c|c|c|c|c|c|c|c|c|c|}
\hline \multirow{2}{*}{ Years } & \multirow{2}{*}{$\begin{array}{l}\text { Depth } \\
(\mathrm{cm})\end{array}$} & Sand & Silt & Clay & \multirow{2}{*}{$\begin{array}{c}\mathrm{Ec} \\
(\mathrm{dS} / \mathrm{m})\end{array}$} & \multirow{2}{*}{$\mathrm{pH}$} & \multirow{2}{*}{$\begin{array}{c}\text { Organic Carbon } \\
(\%)\end{array}$} & \multirow{2}{*}{$\begin{array}{l}\mathrm{N} \\
(\%)\end{array}$} & $\mathrm{P}$ & $\mathrm{K}$ & $\mathrm{Zn}$ & $\mathrm{Fe}$ & $\mathrm{Mn}$ \\
\hline & & & $(\%)$ & & & & & & & & \multicolumn{3}{|c|}{$(\mathrm{mg} / \mathrm{kg})$} \\
\hline 2014- & $0-30$ & 26 & 42 & 32 & 0.83 & 7.3 & 0.8 & 0.08 & 8.2 & 188 & 0.52 & 3.9 & 9.12 \\
\hline 15 & $30-60$ & 26 & 31 & 43 & 1.04 & 7.3 & 0.51 & 0.05 & 7.5 & 156 & 0.31 & 2.9 & 6.2 \\
\hline 2015- & $0-30$ & 29 & 35 & 36 & 1.10 & 7.4 & 0.82 & 0.07 & 9 & 155 & 0.8 & 5.8 & 10.6 \\
\hline 16 & $30-60$ & 27 & 29 & 44 & 1.60 & 7.3 & 0.61 & 0.066 & 6.6 & 131 & 0.4 & 4.6 & 6.6 \\
\hline
\end{tabular}




\section{Treatments and experimental design}

Experiment was conducted in a factorial randomized complete block design with three replications. Experimental factors include AMF species Glamus intraradices strain of BEG11 (inoculated (M1) and non-inoculated (M0)), strains of Pseudomonas (four strains of Pseudomonas bacteria, including S153, S169, S4, S8 and a control (without inoculation) and barley cultivars (Dasht and Sahra cultivars).

\section{Preparation and characterization of Pseudomonas strains}

These Pseudomonas strains were isolated from soil samples collected from fields in Ardebil province, Iran. The strains were evaluated for their siderophores, P-solubilizing capability, acid and alkaline $\mathrm{pH}$, and produces the phytohormone indole-3-acetic acid (IAA) (Alishahi et al., 2013). Pseudomonas strains was characterized as described below:

Siderophore production by Pseudomonas strains were tested on universal Chrome Azurol S (CAS) agar (Schwyn and Neilands, 1987). The bacterial strain was inoculated at the center of the plate and incubated at $28{ }^{\circ} \mathrm{C}$ for 3 days. Siderophores production were detected by a halo of color change from blue to orange on the CAS medium and measured in triplicate as the ratio between the two diameters of the halo and the two colony diameters.

Phosphate solubilization by Pseudomonas strains were assayed according to Goldstein (1986), using two different media, one containing dicalcium phosphate (DCP) $\left(\mathrm{NH}_{4} \mathrm{Cl} 4.25 \mathrm{~g} \mathrm{l}^{-1}, \mathrm{NaCl} 0.85 \mathrm{~g} \mathrm{l}^{-1}\right.$, glucose $8.5 \mathrm{~g} \mathrm{l}^{-1}, \mathrm{MgSO}_{4} 7 \mathrm{H}_{2} \mathrm{O} 0.85 \mathrm{~g} \mathrm{l}^{-1}, \mathrm{~K}_{2} \mathrm{HPO}_{4} 2$ $\mathrm{g} \mathrm{l}^{-1}, \mathrm{CaCl}_{2} 2 \mathrm{H}_{2} \mathrm{O} 4 \mathrm{~g} \mathrm{l}^{-1}$, agar $17 \mathrm{~g} \mathrm{l}^{-1}$ ) and one containing tricalcium phosphate (TCP) $\left(\mathrm{NH}_{4} \mathrm{Cl} 5 \mathrm{~g} \mathrm{l}^{-1}, \mathrm{NaCl} 1 \mathrm{~g} \mathrm{l}^{-1}, \mathrm{MgSO}_{4} 7 \mathrm{H}_{2} \mathrm{O} 1 \mathrm{~g} \mathrm{l}^{-1}\right.$, glucose $10 \mathrm{~g} \mathrm{l}^{-1}, \mathrm{Ca}_{3}\left(\mathrm{PO}_{4}\right)_{2} 40 \mathrm{~g} \mathrm{l}^{-1}$, agar $20 \mathrm{~g} \mathrm{l}^{-1}$ ). The strains were inoculated at the center of the plate and incubated at 28 ${ }^{\circ} \mathrm{C}$ for 15 days. DCP solubilization was indicated by a clarification halo around the colony; TCP solubilization was identified by a colony growth on the media.

Indole-3-acetic acid (IAA) production by Pseudomonas strains were quantified according to De Brito Alvarez et al. (1995). The bacterial strain was inoculated onto a nitrocellulose disk placed on trypticase soy agar (TSA) with $10 \%$ added to Ltryptophan $(5 \mathrm{mM})$ and incubated at $28{ }^{\circ} \mathrm{C}$ for 3 days. The membrane was then stained with the Salkowskys reagent $\left(\mathrm{FeCl}_{3} 2 \%\right.$ in percloric acid $\left.35 \%\right)$, the presence of a $\mathrm{red} /$ pink halo around the colony indicated a positive reaction.

The 1-aminocyclopropane-1-carboxylate (ACC) deaminase enzyme activity was assayed based on Penrose and Glick (2001) method which measures the amount of $\alpha$ ketobutyrate produced when the enzyme ACC deaminase cleaves ACC. The $\mu$ mole quantity of $\alpha$-ketobutyrate produced by this reaction was determined by comparing the absorbance of a sample to a standard curve of $\alpha$-ketobutyrate ranging between 0.1 and $1.0 \mathrm{nmol}$ at $540 \mathrm{~nm}$. A stock solution of $\alpha$ - ketobutyrate was prepared in $0.1 \mathrm{M}$ Tris- $\mathrm{HCl}$ $(\mathrm{pH} 8.5)$ and stored at $4 \mathrm{o}{ }^{\circ} \mathrm{C}$. In order to measure the specific activity of the cultures, protein estimation was carried out according to Lowry et al. (1951). Pseudomonas strains characterized are presented in Table 2.

Table 2. Characteristics of Pseudomonads strains

\begin{tabular}{|c|c|c|c|c|}
\hline Pseudomonas Strains & $\begin{array}{l}\text { Phosphorus } \\
\text { solubilizing } \\
\text { activity }\end{array}$ & $\begin{array}{l}\text { ACC-deaminase } \\
\text { activity } \\
\mu \text { moles } \mathrm{mg}^{-1} \mathrm{~h}^{-1}\end{array}$ & $\begin{array}{l}\text { IAA production } \\
\left(\mathrm{mg} \mathrm{L}^{-1}\right)\end{array}$ & $\begin{array}{c}\text { Siderophore production } \\
\text { (halo diameter/colony } \\
\text { diameter) }\end{array}$ \\
\hline P. fluorescens strain 153 & + & 4.61 & 3.1 & 1.6 \\
\hline P. fluorescens strain 169 & + & 4.45 & 2.8 & 1.5 \\
\hline P. putida strain 4 & + & 8.17 & 6.6 & 1.7 \\
\hline P. putida strain 8 & + & 7.34 & 5.9 & 1.6 \\
\hline
\end{tabular}


The bacterial strains were kept in nutrient broth with $15 \%$ glycerol at $-80{ }^{\circ} \mathrm{C}$ for long-term storage. For this experiment, a single colony was transferred to $500 \mathrm{~mL}$ flasks containing NBRIP and grown aerobically on a rotating shaker for $48 \mathrm{~h}$ at $27{ }^{\circ} \mathrm{C}$ and 150 rpm. The bacterial suspension was then diluted in sterile distilled water to a final concentration of $10^{8}$ colony forming units (CFU) $\mathrm{mL}^{-1}$, and the resulting suspensions were used for the experiment.

\section{Experimental plots, seed inoculation and sowing}

Before sowing, barley seeds were soaked by Arabic gum and active bacteria were added to seeds. After inoculation, seeds were dried on a surface sterilized plastic sheet in laminar flow.

The AMF inoculum contained colonized root fragments, sand, AMF hyphae and spores. The inoculum was blended with an inert material for solution and homogenizing the distribution in the soil. A 50-g portion of inoculum was added to each plot at sowing time just below the seeds (Vazquez et al., 2002). The AMF was obtained from the culture collection of the Soil and Water Research Institute (SWRI), Iran.

The first effective rainfall was in November 23 and cultivation operation began after it. In the fall and before planting, plowing operation and disc were conducted and after land leveling, the seeds were planted with density of 400 seeds per $\mathrm{m}^{2}$. Plots were 6 rows, 5 meters long, and spaced $20 \mathrm{~cm}$. Hand weeding was operated after planting. Farm management was conducted conforming to organic farming principles with no application of chemical materials.

Sampling of mycorrhizal colonization and plant height, yield components, seed yield, and biological yield

The mycorrhizal colonization was enumerated using the method of Philips and Hayman (1970). The roots were examined under a microscope and the percent of root colonization was determined by dividing the number of colonized roots by the number of total roots examined.

In physiological maturity stage, sampling of middle lines of each plot was conducted with respect to the sidelines and among competing bushes. To calculate the plant height, number of fertile tiller per plant, seeds per spike and thousand kernel weight (weight of 1000 seeds), samples taken from 10 plants were randomly selected and counted in each of 10 plants. Then, their mean was calculated in each plant. Seed yield was measured from middle rows of each experiment plot with $1 \mathrm{~m}^{2}$ area. For measuring biological yield, the samples were dried for $72 \mathrm{~h}$ at $70{ }^{\circ} \mathrm{C}$ in an oven. Harvest index was calculated by following formula:

$$
\text { Harvest index }(\%)=\frac{\text { Seed yield }(\mathrm{kg} / \mathrm{ha})}{\text { Biologicalyield }(\mathrm{kg} / \mathrm{ha})} \times 100
$$

\section{Nutrient analysis}

The seed nitrogen $(\mathrm{N})$ content was determined following the semi-micro Kjedahl procedure using a nitrogen analyzer (Kjedahl, 2300; FOSS, Hoganas, Sweden). The phosphorus (P) content was estimated using the vanadomolybdo-phosphoric colorimetric method (Jackson, 1962). Uptake of seed elements was calculated by following formula: 
Element uptake $(\mathrm{kg} / \mathrm{ha})=\frac{\text { Seed yield }(\mathrm{kg} / \mathrm{ha}) \times \text { Element concentration }(96)}{100}$

\section{Statistical analysis}

Experimental data were analyzed statistically using ANOVA. Significance of the effect of treatment was determined by the magnitude of the F-value $(P \leq 0.05)$. When a significant F-test was obtained for the treatments, separation of means were done using the LSMEANS procedure with LSD adjustment at $P=0.05$. Statistical analysis of the results was performed using general linear model (GLM) in SAS software version 9.2.

\section{Results and Discussion}

\section{Plant height}

The results demonstrated that the interaction effect of Pseudomonas $\times$ AMF $\times$ cultivars $\times$ year had significant on plant height was significant $(P<0.05)($ Table 3$)$. Mean comparison showed that in the first year in the Sahra cultivar at the AMF inoculation levels, there was no significant difference between the Pseudomonas strains. Nevertheless, in the Sahra at the AMF non-use conditions, control $(76.96 \mathrm{~cm})$ exhibited the greatest height.

In the second year, in both cultivars, S4 strain in comparison to other Pseudomonas strains produced more height $(0.7-29.5 \%$ and $1.1-16.5 \%$ under AMF use and non-use conditions, respectively), although there was no significant difference between some strains and control (Table 4). Increasing the plant height plays an important role in the remobilization of photosynthetic materials to seeds during seed filling period (Sharma et al., 2014). Vazquez et al. (2000) on their investigation on wheat also reported that AMF and cultivar had significant effect on plant height, but the effect of bacteria on plant height was not statistically significant.

The useful impact of AMF in uptake of water and elements required by plant through root and root development and increased uptake of elements in the soil to be used by plant, which caused increased in height. Roesti et al. (2006) reported that PGPR strains and AMF can synergistically improve the height of wheat without negatively affecting AMF growth. We also found that the impact of Pseudomonas strains on plant height was stronger in AMF-treated plants than untreated plants. This result was in line with the result of the study performed by Chaurasia and Khare (2005).

\section{The number of tiller and number of seed per spike}

The interaction effect of Pseudomonas $\times$ AMF $\times$ cultivars $\times$ year on number of tiller was significant $(P<0.05)$ (Table 3). Mean comparison of the number of tillers showed that in the first year in the Dasht cultivar, though Pseudomonas strains were superior compared to control, significant differences were not found between strains. Nevertheless, in Sahra cultivar, both in conditions of consumption and non-AMF conditions, strains of bacteria were superior to the control (10-54\% and 5-46\% under AMF use and non-use conditions, respectively), while this superiority in some strains was not significant and strain S4 had significant superiority compared to other strains (5.5-32\% and 12-28\% under AMF use and non-use conditions, respectively). 
In the second year, in both cultivars, in the presence and absence of AMF, Pseudomonas strains compared to control had significant superiority (16.1-55.2\% and $3.3-46 \%$ under AMF use and non-use conditions, respectively) and strain S4 compared to other strains had significant superiority (7.0-13.3\% and 5.1-29.6\% under AMF use and non-use conditions, respectively) (Table 4). In total, in both cultivars, application of AMF led to increased influence of Pseudomonas strains and the number of tillers in plant.

The interaction effect of Pseudomonas $\times$ AMF $\times$ cultivars $\times$ year on seed per spike was significant $(P<0.05)$ (Table 3). Comparison of the mean interaction effect of AMF and Pseudomonas strains inoculation with barley cultivars on seed number in the spike also revealed that in the first year in the Sahra cultivar in AMF non-use conditions, there was no significant difference between Pseudomonas strains and control, and at the AMF use conditions, only strain S4 had superiority compared to control (25.7\%). In the Sahra cultivar in AMF non-use conditions, with the exception of strain S4, other strains did not demonstrate any significant difference compared to control. Nevertheless, the use of AMF in plants inoculated with Pseudomonas strains increased the number of seeds per spike significantly compared to control (29.0-41.9\%). In the second year, in the Dasht cultivar, Pseudomonas strains showed significant superiority compared to control (8.9$31.3 \%$ and 15.2-23.6\% under AMF use and non-use conditions, respectively), however in the AMF non-use conditions, there was no significant difference between the strains of Pseudomonas. In the Sahra cultivar, similar trend was observed, while in the AMF use conditions, significant difference was not seen between the S169 strain and control. In total, in both years and cultivars, the maximum number of seeds per spike was obtained from S4 strain under the use of AMF (Table 4). Given that tillers are determined earlier than flowering stage, inoculation of seeds with growth stimulating bacteria increased the number of fertile tiller.

Table 3. Analysis of variance effect of barley cultivars under AMF and Pseudomonas inoculation on plant height, tiller number, seed number, thousand kernel weight, biological yield, seed yield and harvest index

\begin{tabular}{|c|c|c|c|c|c|c|c|c|}
\hline \multirow[b]{2}{*}{ S.O.V } & \multirow[b]{2}{*}{ df } & \multicolumn{7}{|c|}{ Mean Square } \\
\hline & & $\begin{array}{l}\text { Plant } \\
\text { height }\end{array}$ & $\begin{array}{c}\text { Fertile tiller number } \\
\text { per plant }\end{array}$ & $\begin{array}{l}\text { Seed number } \\
\text { per spike }\end{array}$ & $\begin{array}{c}\text { Thousand kernel } \\
\text { weight }\end{array}$ & $\begin{array}{l}\text { Biological } \\
\text { yield }\end{array}$ & $\begin{array}{l}\text { Seed } \\
\text { yield }\end{array}$ & $\begin{array}{l}\text { Harvest } \\
\text { index }\end{array}$ \\
\hline Y (Year) & 1 & $1266 * *$ & $0.675^{*}$ & $110.5^{* *}$ & $508.4^{* *}$ & $28256107 * *$ & $2935321 * *$ & $0.595 \mathrm{~ns}$ \\
\hline Year / Rep & 4 & $99.31 *$ & $0.2067 \mathrm{~ns}$ & $215.5^{* *}$ & $6.46 \mathrm{~ns}$ & $936534 * *$ & $418409 * *$ & $50.72 \mathrm{~ns}$ \\
\hline Cultivar (C) & 1 & $20.17 \mathrm{~ns}$ & $1.012 * *$ & $708.5^{* *}$ & $33.2 \mathrm{~ns}$ & $815925 *$ & $1445468 * *$ & $2548 * *$ \\
\hline $\operatorname{AMF}(\mathrm{M})$ & 1 & $13.87 \mathrm{~ns}$ & $0.799 *$ & $6.912 \mathrm{~ns}$ & $139.5^{* *}$ & $160235 \mathrm{~ns}$ & 53093.ns & $33.40 \mathrm{~ns}$ \\
\hline Bacteria (B) & 4 & $95.02 *$ & $0.853^{* *}$ & $24.75 \mathrm{~ns}$ & $143.4^{* *}$ & $179551 \mathrm{~ns}$ & $129393 * *$ & $23.41 \mathrm{~ns}$ \\
\hline $\mathrm{Y} \times \mathrm{C}$ & 1 & $17.48 \mathrm{~ns}$ & $10.19^{* *}$ & $3.201 \mathrm{~ns}$ & $52.53 \mathrm{~ns}$ & 1253585 *** & $441.90 \mathrm{~ns}$ & $1276^{* *}$ \\
\hline $\mathrm{Y} \times \mathrm{M}$ & 1 & $6.44 \mathrm{~ns}$ & $0.935^{*}$ & $6.912 \mathrm{~ns}$ & $9.78 \mathrm{~ns}$ & $719975 *$ & 18355.ns & $156.65^{* *}$ \\
\hline $\mathrm{Y} \times \mathrm{B}$ & 4 & $33.65 \mathrm{~ns}$ & $2.201^{* *}$ & $68.29 *$ & $223.56 * *$ & $379174 n s$ & $72103 * *$ & $65.00^{*}$ \\
\hline $\mathrm{C} \times \mathrm{M}$ & 1 & $0.027 \mathrm{~ns}$ & $0.257 \mathrm{~ns}$ & $25.76 \mathrm{~ns}$ & $11.40 \mathrm{~ns}$ & $453870 \mathrm{~ns}$ & $394.5 \mathrm{~ns}$ & $78.44^{*}$ \\
\hline $\mathrm{C} \times \mathrm{B}$ & 4 & $42.76 \mathrm{~ns}$ & $0.191 \mathrm{~ns}$ & $73.33^{*}$ & $9.53 \mathrm{~ns}$ & $262673 n s$ & $33745 \mathrm{~ns}$ & $42.28 \mathrm{~ns}$ \\
\hline $\mathrm{M} \times \mathrm{B}$ & 4 & $92.92 *$ & $0.903^{* *}$ & $8.03 \mathrm{~ns}$ & $38.90 \mathrm{~ns}$ & $357051 \mathrm{~ns}$ & $31251 \mathrm{~ns}$ & $133 * *$ \\
\hline $\mathrm{M} \times \mathrm{B} \times \mathrm{C}$ & 4 & $34.25 \mathrm{~ns}$ & $1.113^{* *}$ & $2.60 \mathrm{~ns}$ & $24.31 \mathrm{~ns}$ & $441103 *$ & $58164 * *$ & $80.68^{* * *}$ \\
\hline $\mathrm{Y} \times \mathrm{C} \times \mathrm{M}$ & 1 & $92.22 \mathrm{~ns}$ & $0.00001 \mathrm{~ns}$ & $2.24 \mathrm{~ns}$ & $32.24 \mathrm{~ns}$ & $28830 \mathrm{~ns}$ & $0.049 \mathrm{~ns}$ & $0.137 \mathrm{~ns}$ \\
\hline $\mathrm{Y} \times \mathrm{C} \times \mathrm{B}$ & 4 & 129.7 ** & $0.146 \mathrm{~ns}$ & $116.9^{* *}$ & $6.31 \mathrm{~ns}$ & $268825 \mathrm{~ns}$ & $45489 *$ & $55.45^{*}$ \\
\hline $\mathrm{Y} \times \mathrm{M} \times \mathrm{B}$ & 4 & $15.37 \mathrm{~ns}$ & $0.863^{*}$ & $58.00 *$ & $16.62 \mathrm{~ns}$ & $263291 \mathrm{~ns}$ & $45088 *$ & $106.1^{* * *}$ \\
\hline $\mathrm{Y} \times \mathrm{C} \times \mathrm{M} \times \mathrm{B}$ & 4 & $60.48 *$ & $0.584^{*}$ & $81.47 *$ & $30.09 \mathrm{~ns}$ & $311117 *$ & $46415^{* *}$ & $59.79 * *$ \\
\hline Error & 76 & 30.95 & 0.136 & 13.98 & 18.19 & 160978 & 15949 & 21.77 \\
\hline $\mathrm{CV}(\%)$ & & 9.06 & 9.77 & 13.56 & 8.35 & 12.13 & 8.33 & 12.52 \\
\hline
\end{tabular}

*, ** Significant at $P<0.05$ and $P<0.01$, respectively. $C V$ : Coefficient of Variation

In both years, some Pseudomonas strains enhanced grain number under AMF use through producing more tillers. In this respect, Shaharoona et al (2008) reported an increase in the number of tillers per plant inoculated with growth promoting bacteria. 
Bacteria used in this experiment can produce ACC deaminase enzyme and this increase in number of tiller can be attributed to this enzyme.

Results of this experiment are in line with results of Nadeem et al. (2007) that reported increased number of tillers in rainfed conditions by growth promoting bacteria. Bacteria mediated changes in the elasticity of the root cell membranes is one of the first steps towards enhanced tolerance to water deficiency (Dimkpa et al., 2009). PGPR improves the stability of plant cell membranes by activating the antioxidant defense system, enhancing drought tolerance in plants (Gusain et al., 2015).

Wagar et al. (2004) reported the effect of AMF in increasing the efficiency of pseudomonas bacteria. Therefore, depending on the strain combination, microbial interactions within AMF had positive effects on inoculant establishment in roots and resulted in enhanced tillers and number of seeds as compared to single inoculation.

Table 4. Interaction effect of Pseudomonas strains $\times A M F \times$ Barley cultivar on plant height, seed per spike and tiller per plant

\begin{tabular}{|c|c|c|c|c|c|c|c|c|}
\hline \multirow[t]{2}{*}{$\begin{array}{c}\text { Barley } \\
\text { cultivars }\end{array}$} & \multirow[t]{2}{*}{ AMF } & \multirow[t]{2}{*}{$\begin{array}{l}\text { Pseudomonas } \\
\text { strains }\end{array}$} & \multicolumn{2}{|c|}{$\begin{array}{l}\text { Plant height } \\
(\mathrm{cm})\end{array}$} & \multicolumn{2}{|c|}{$\begin{array}{l}\text { Seed number } \\
\text { per spike }\end{array}$} & \multicolumn{2}{|c|}{$\begin{array}{c}\text { Fertile tiller } \\
\text { number per plant }\end{array}$} \\
\hline & & & $\mathrm{Y} 1$ & $\mathrm{Y} 2$ & Y1 & $\mathrm{Y} 2$ & Y1 & $\mathrm{Y} 2$ \\
\hline \multirow{5}{*}{ Dasht } & \multirow{5}{*}{ M0 } & Control & $73.16 a$ & $50.10 b$ & $19.36 \mathrm{a}$ & $23.00 \mathrm{~b}$ & $3.46 a$ & $2.77 \mathrm{~d}$ \\
\hline & & S153 & $70.96 a$ & $55.76 \mathrm{ab}$ & $21.00 \mathrm{a}$ & $28.33 \mathrm{a}$ & $4.36 \mathrm{a}$ & $3.41 \mathrm{c}$ \\
\hline & & S169 & $74.63 \mathrm{a}$ & $49.06 \mathrm{~b}$ & $19.50 \mathrm{a}$ & $28.33 \mathrm{a}$ & $4.16 \mathrm{a}$ & $3.65 \mathrm{bc}$ \\
\hline & & S4 & $75.73 a$ & $49.36 b$ & $19.50 \mathrm{a}$ & $26.66 a$ & $4.20 \mathrm{a}$ & $4.00 \mathrm{a}$ \\
\hline & & S8 & $73.70 \mathrm{a}$ & $58.53 \mathrm{a}$ & $20.06 \mathrm{a}$ & $28.00 \mathrm{a}$ & $4.13 a$ & $3.79 \mathrm{ab}$ \\
\hline \multirow{5}{*}{ Dasht } & \multirow{5}{*}{ M1 } & Control & $69.90 \mathrm{a}$ & $48.53 \mathrm{ab}$ & $20.70 \mathrm{~b}$ & $22.333 d$ & $3.66 \mathrm{a}$ & $2.84 \mathrm{c}$ \\
\hline & & S153 & $71.46 \mathrm{a}$ & $58.03 \mathrm{a}$ & $22.43 b$ & $26.000 \mathrm{~b}$ & $3.93 \mathrm{a}$ & $3.82 \mathrm{~b}$ \\
\hline & & S169 & $74.06 \mathrm{a}$ & $57.03 \mathrm{ab}$ & $21.63 b$ & $24.333 \mathrm{c}$ & $4.23 a$ & $4.10 \mathrm{ab}$ \\
\hline & & S4 & $72.96 a$ & $60.03 a$ & $26.03 a$ & $29.333 a$ & $4.36 \mathrm{a}$ & $4.41 \mathrm{a}$ \\
\hline & & S8 & $69.80 \mathrm{a}$ & $42.10 \mathrm{~b}$ & $20.83 b$ & $26.333 b$ & $4.33 \mathrm{a}$ & $4.00 \mathrm{ab}$ \\
\hline \multirow{5}{*}{ Sahra } & \multirow{5}{*}{ M0 } & Control & $76.96 \mathrm{a}$ & $51.86 a$ & $31.80 \mathrm{~b}$ & $26.00 \mathrm{~b}$ & $2.66 \mathrm{~b}$ & $3.10 \mathrm{~d}$ \\
\hline & & S153 & 69.76ab & $50.43 a$ & $30.13 b$ & $31.33 \mathrm{a}$ & $2.80 \mathrm{~b}$ & $3.57 \mathrm{c}$ \\
\hline & & S169 & $65.66 b$ & $52.13 \mathrm{a}$ & $28.80 \mathrm{~b}$ & $30.66 \mathrm{a}$ & $3.43 \mathrm{ab}$ & $4.23 b$ \\
\hline & & S4 & $73.80 \mathrm{ab}$ & $54.72 \mathrm{a}$ & $36.90 \mathrm{a}$ & $31.33 \mathrm{a}$ & $3.90 \mathrm{a}$ & $4.56 \mathrm{a}$ \\
\hline & & $\mathrm{S} 8$ & $72.80 \mathrm{ab}$ & $54.36 \mathrm{a}$ & $31.43 \mathrm{~b}$ & $31.66 \mathrm{a}$ & $3.43 \mathrm{ab}$ & $3.20 \mathrm{~cd}$ \\
\hline \multirow{5}{*}{ Sahra } & \multirow{5}{*}{ M1 } & Control & $64.93 c$ & $44.20 \mathrm{~b}$ & $25.03 c$ & $28.00 \mathrm{c}$ & $2.56 c$ & $3.65 b$ \\
\hline & & S153 & $79.06 \mathrm{a}$ & $46.80 \mathrm{ab}$ & $34.83 \mathrm{ab}$ & 33.00ab & $3.23 \mathrm{bc}$ & $4.25 \mathrm{ab}$ \\
\hline & & S169 & 73.40abc & $48.53 \mathrm{ab}$ & $34.43 \mathrm{ab}$ & $29.00 c$ & $2.83 c$ & $4.25 \mathrm{ab}$ \\
\hline & & S4 & $69.86 b c$ & $54.86 \mathrm{a}$ & $35.53 \mathrm{a}$ & $34.66 \mathrm{a}$ & $4.20 \mathrm{a}$ & $4.78 \mathrm{a}$ \\
\hline & & S8 & 79.56ab & $54.80 \mathrm{a}$ & $32.30 \mathrm{~b}$ & $32.33 b$ & $3.96 a b$ & $4.49 \mathrm{ab}$ \\
\hline
\end{tabular}

Means within a column followed by the same letter are not significantly $(P<0.05)$ different according to LSD test. $(Y 1=2014-2015 ; Y 2=2015-2016)(M 0=A M F$ non-use; $M 1=A M F$ use $)$

\section{Thousand kernel weight}

Results of analysis of variance revealed that the main effect of AMF and interaction effect of bacteria $\times$ year on seed weight was significant $(P<0.01)$ (Table 3). Mean comparisons of AMF impact on thousand kernel weight revealed that use of AMF increased thousand kernel weight by $11.2 \%$ compared to non-use of AMF (Figure 3). AMF provided more water to plant by increasing uptake level, thus during the seed filling, it can help the plant and increase the weight of seeds (Estrada-Campuzano et al., 2012). A comparison of the mean interaction effect of bacteria $\times$ year also revealed that in both years, the control in comparison to Pseudomonas strains was superior (Figure 
4). Thousand kernel low weight in rainfed conditions is due to competition of seeds in obtaining food and reduced carbohydrate stored by plant such that number of cells produced decreases and thousand kernel weight decreases, while AMF played a significant role in increasing weight of wheat seeds (Arshad et al., 2008). Allahverdiyev et al. (2015) reported that in other crops such as wheat, inverse relationship was observed between yield elements, such that with changes in yield elements, the production amount cannot be increased from the final range. It seems that increasing adequate water supply from the beginning of plant growth leads to increased tillering and number of leaf. Generally, it leads to increased yield elements and thus seed yield.

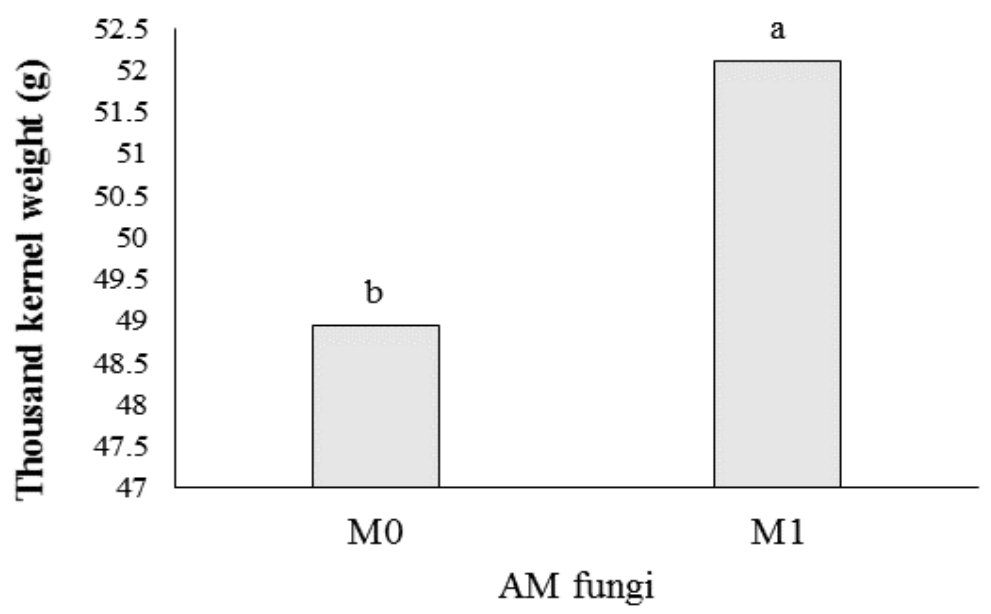

Figure 3. Main effect of AMF on thousand kernel weight $M O=A M F$ non-use; $M 1=A M F$ use $;$ Means in each column followed by at least one similar letter are not significantly different at $5 \%$ probability level, using LSD test

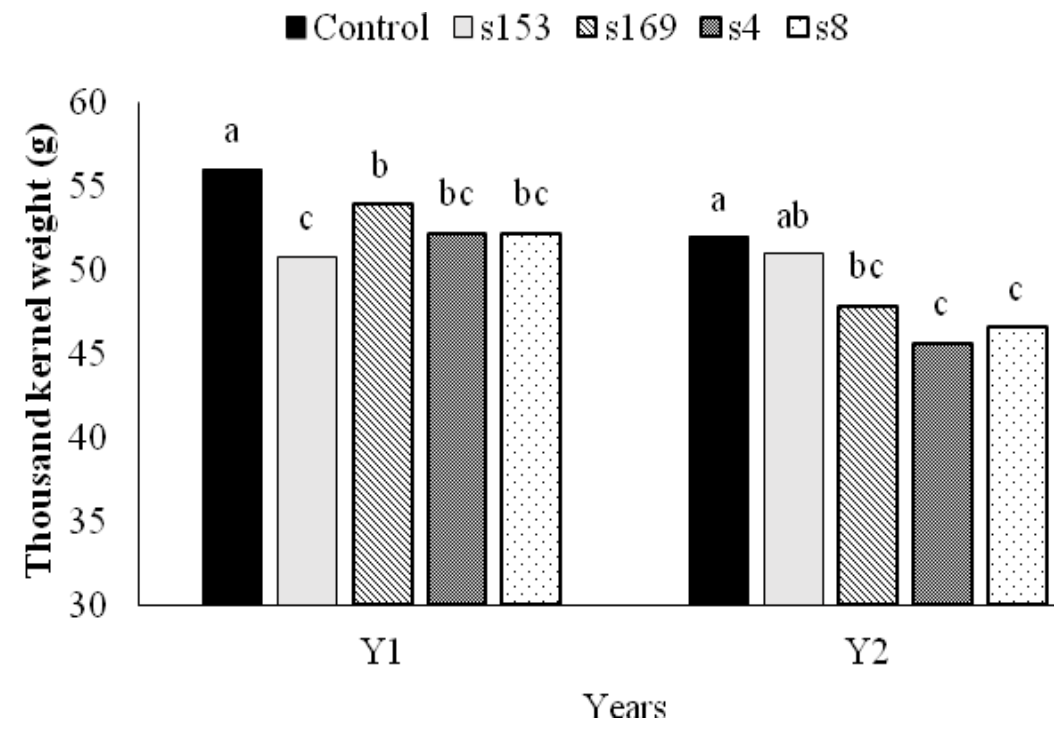

Figure 4. Interaction effect of Pseudomonas strains $\times$ year on thousand kernel weight; $Y 1=$ 2014-2015; Y2 = 2015-2016. Means in each column followed by at least one similar letter are not significantly different at 5\% probability level, using LSD test 


\section{Biological yield}

The interaction effect of Pseudomonas $\times$ AMF $\times$ cultivars $\times$ year on biological yield was significant $(P<0.05)$ (Table 3). The comparison of mean showed that in the first year in the Dasht cultivar, the use of AMF increased the biological yield such that S4 strain (which showed the highest biological yield) in the conditions of AMF usage, caused increased biological yield of $22.73 \%$ in comparison to control. However, at the conditions of AMF non-use, biological yield increased by $14.66 \%$. In the Sahra cultivar, S4 strain in both AMF using and non-using conditions had superiority in comparison to other strains of Pseudomonas (24.2\% and $27.8 \%$ under AMF use and non-use conditions, respectively, in comparison to control), while significant difference was not found between some strains and control.

In the second year in the Dasht cultivar, the AMF use led to significant superiority of Pseudomonas strains compared to the control (10.2-18.3\%), such that even in the control, the use of AMF increased biological yield by $5.47 \%$ in comparison to AMF non-use condition. In the Sahra cultivar in conditions of using AMF, only S4 strain had significant superiority compared to control (33.8\%) and there was no significant difference between other strains of Pseudomonas and control (Table 5).

The increase in biological yield by soil and seed inoculation of Pseudomonas strains and AMF at different conditions has been reported by many researchers (Germida and Walley, 1996, Shaharuna et al., 2008). Khan et al. (2003) in the review of research conducted on growth stimulating bacteria reported the significant effect of inoculation with $P$. fluorescent on dry weight of aerial part of barley. Growth stimulating microorganisms such as Pseudomonas and AMF can provide optimum conditions to increase biomass by creating positive variations on soil physical and chemical properties around the root, and the timely provision of required elements during the growing season (Esfahani et al., 2009). Messele and Pant (2012) observed improved biological yield and $\mathrm{P}$ uptake in chickpea (Cicer arietinum L.) by phosphatesolubilizing Pseudomonas. An increase in $\mathrm{P}$ availability to plants through the action of phosphate-solubilizing bacteria (PSB) has also been reported for wheat (Panhwar et al., 2011). Application of plant growth stimulating bacteria that can also produce the enzyme ACC deaminase and alongside AMF can provide the elements needed by plant and lead to increased plant growth (Lingua et al., 2003). Their synergistic interaction increased N, P and K uptake by plants under water deficit conditions (Malfanov et al., 2011). Strains appear to have some plant growth-promoting activities, such as IAA production and solubilization of phosphate, which together or alone might explain the capacity of Pseudomonas strains to improve plant growth and nutrient acquisition.

\section{Seed yield}

The interaction effect of Pseudomonas $\times$ AMF $\times$ cultivars $\times$ year on seed yield was significant $(P<0.01)$ (Table 3). A comparison of the mean interaction effect of Pseudomonas and the AMF on seed yield of barley cultivars revealed that in the first year at Dasht cultivar using AMF conditions, significant differences were not observed between Pseudomonas strains. However, the use of AMF led to increased seed yield in all strains and even in control and S4 strain with yield of $1293 \mathrm{~kg} / \mathrm{ha}$ which increased seed yield by $17.63 \%$ compared to control. In the Sahra cultivar, Pseudomonas strains increased seed yield at both levels of AMF. 
In the second year at Dasht cultivar in both levels of AMF, strains of Pseudomonas when compared with control showed significant superiority and at the level of AMF non-use conditions, strain S8 with mean of $1529 \mathrm{~kg} / \mathrm{ha}$ and at the AMF use conditions, strain S4 with mean of $1912 \mathrm{~kg} / \mathrm{ha}$ (had no significant difference with S169) exhibited the highest seed yield. In the Sahra cultivar, Pseudomonas strains increased seed yield in comparison to control, and S4 increased seed yield by $13.33 \%$ at AMF non-use conditions and $18.66 \%$ at AMF use conditions (Table 5). The effect of microorganisms on plant depends on many factors such as soil organic matter, the amount of existing elements in the soil, soil texture, soil moisture, strain type, and plant cultivar (Vessey, 2003). The relationship between plant cultivars and strains have been reported in the studies of Kader et al. (2002) and Dijkman et al. (2017). Nonetheless, with increased seed yield in AMF non-use conditions, Pseudomonas strains compared to control caused increase in seed yield in Sahra cultivar, but the increase in seed yield is increased by adding AMF, and in the Dasht cultivar, its efficiency of bacterial inoculation is increased. The effect of AMF on the increased efficiency of bacterial inoculation has been reported by Sexena and Jha (2014). However, increase in seed yield can be attributed to the role of AMF and P. Putida in increasing uptake of elements such as Fe and P (Vessey, 2003). However, partial increase in barley seed yield can be attributed to the secretion of plant hormones secreted such as Auxin- by microorganisms. Secretion of IAA and other plant growth hormones in canola, wheat, and tomatoes inoculated with P. Putida has been reported by Mayak et al. (2004). In addition, plant growth stimulating microorganisms affect the root morphology and size and thus affect the root ability in accessing larger volume of soil. Consequently, they increase uptake of water and plants yield (Arshad et al., 2008).

Table 5. Interaction effect of Pseudomonas strains $\times A M F \times$ Barley cultivars on biological yield, seed yield and harvest index

\begin{tabular}{|c|c|c|c|c|c|c|c|c|}
\hline \multirow{2}{*}{$\begin{array}{l}\text { Barley } \\
\text { cultivar }\end{array}$} & \multirow[t]{2}{*}{ AMF } & \multirow{2}{*}{$\begin{array}{c}\text { Pseudomonas } \\
\text { strains }\end{array}$} & \multicolumn{2}{|c|}{$\begin{array}{l}\text { Biological yield } \\
\text { (kg/ha) }\end{array}$} & \multicolumn{2}{|c|}{$\begin{array}{l}\text { Seed yield } \\
(\mathrm{kg} / \mathrm{ha})\end{array}$} & \multicolumn{2}{|c|}{$\begin{array}{l}\text { Harvest index } \\
(\%)\end{array}$} \\
\hline & & & $\mathrm{Y} 1$ & $\mathrm{Y} 2$ & Y1 & $\mathrm{Y} 2$ & Y1 & $\mathrm{Y} 2$ \\
\hline \multirow{5}{*}{ Dasht } & \multirow{5}{*}{ M0 } & Control & $2269 c$ & $3453 a$ & $1007 \mathrm{a}$ & 1141d & $26.28 b$ & $33.20 \mathrm{c}$ \\
\hline & & S153 & $2781 \mathrm{ab}$ & $3946 a$ & $1096 \mathrm{a}$ & $1276 \mathrm{c}$ & $26.72 \mathrm{ab}$ & $39.42 \mathrm{ab}$ \\
\hline & & S169 & $2829 \mathrm{ab}$ & $3893 a$ & $1106 a$ & $1377 b c$ & $27.44 \mathrm{ab}$ & $38.35 \mathrm{ab}$ \\
\hline & & S4 & 2949a & $4133 a$ & $1205 \mathrm{a}$ & $1440 \mathrm{ab}$ & $33.11 \mathrm{a}$ & $40.50 \mathrm{a}$ \\
\hline & & S8 & $2493 b c$ & $3920 \mathrm{a}$ & $1081 \mathrm{a}$ & $1529 \mathrm{a}$ & $28.55 \mathrm{ab}$ & $35.72 b c$ \\
\hline \multirow{5}{*}{ Dasht } & \multirow{5}{*}{ M1 } & Control & $2439 c$ & $3653 b$ & $1065 \mathrm{c}$ & $1198 d$ & $33.41 \mathrm{a}$ & $42.46 a$ \\
\hline & & S153 & $3120 \mathrm{ab}$ & 4133ab & $1212 \mathrm{ab}$ & $1385 \mathrm{c}$ & $29.88 \mathrm{a}$ & $31.13 b$ \\
\hline & & S169 & $2787 \mathrm{c}$ & $4026 \mathrm{ab}$ & $1179 \mathrm{abc}$ & $1830 \mathrm{a}$ & $33.51 \mathrm{a}$ & $33.32 b$ \\
\hline & & S4 & $3158 \mathrm{a}$ & $4323 a$ & $1293 a$ & $1912 \mathrm{a}$ & $26.52 \mathrm{a}$ & $33.30 \mathrm{~b}$ \\
\hline & & S8 & $2895 b c$ & 4090ab & $1204 \mathrm{ab}$ & $1642 b$ & $27.73 \mathrm{a}$ & $33.41 \mathrm{~b}$ \\
\hline \multirow{5}{*}{ Sahra } & \multirow{5}{*}{ M0 } & Control & $2416 b$ & $2693 b$ & $1414 c$ & $1652 \mathrm{c}$ & $37.28 b$ & $40.24 a$ \\
\hline & & S153 & $2825 \mathrm{ab}$ & $3293 a b$ & $1600 \mathrm{~b}$ & $1803 a b$ & $42.49 \mathrm{ab}$ & $38.61 \mathrm{ab}$ \\
\hline & & S169 & $2935 \mathrm{ab}$ & $3440 \mathrm{ab}$ & $1564 b$ & $1771 b$ & $40.85 \mathrm{ab}$ & $34.64 b$ \\
\hline & & S4 & $3075 a$ & $3993 a$ & $1726 a$ & $1906 a$ & $45.40 \mathrm{ab}$ & $34.82 b$ \\
\hline & & S8 & $2638 \mathrm{ab}$ & $3820 \mathrm{a}$ & $1618 b$ & $1727 \mathrm{bc}$ & $47.04 \mathrm{a}$ & $37.92 \mathrm{ab}$ \\
\hline \multirow{5}{*}{ Sahra } & \multirow{5}{*}{ M1 } & Control & $2524 b$ & $3466 b$ & $1447 \mathrm{c}$ & $1577 d$ & $41.48 \mathrm{ab}$ & $41.93 a$ \\
\hline & & S153 & $2570 b$ & $3706 b$ & $1637 \mathrm{ab}$ & $1837 b$ & $44.88 \mathrm{a}$ & $39.72 \mathrm{ab}$ \\
\hline & & S169 & $2963 \mathrm{ab}$ & $3560 b$ & $1465 b c$ & $1839 b$ & $40.46 \mathrm{ab}$ & $37.46 \mathrm{~b}$ \\
\hline & & S4 & $3150 \mathrm{a}$ & $4640 \mathrm{a}$ & $1752 \mathrm{a}$ & $1939 a$ & $37.85 b$ & $40.08 \mathrm{ab}$ \\
\hline & & S8 & $2820 \mathrm{ab}$ & $3506 \mathrm{~b}$ & $1491 b c$ & $1736 \mathrm{c}$ & $38.83 b$ & $35.42 \mathrm{c}$ \\
\hline
\end{tabular}

Means within a column followed by the same letter are not significantly $(P<0.05)$ different according to LSD test. $(Y 1=2014-2015 ; Y 2=2015-2016)(M 0=A M F$ non-use; $M 1=A M F$ use $)$ 


\section{Harvest index}

The interaction effect of Pseudomonas $\times$ AMF $\times$ cultivars $\times$ year on harvest index was significant $(P<0.01)$ (Table 3). The mean comparison revealed that in the Dasht cultivar at the AMF use condition, there was no significant difference between strains, but at AMF non-use condition, Pseudomonas strains had significant superiority when compared to control and S4 showed the highest harvest index. In Sahra cultivar, at the AMF use conditions, strains S8, and at the AMF non-use conditions, S153 had the highest harvest index. In the second year, only the Dasht cultivar and at the AMF use conditions, strain S4 demonstrated maximum harvest index, but at the AMF use conditions in the Dasht cultivar and in Sahra cultivar at both AMF use and non-use conditions, control exhibited the greatest harvest index (Table 5).

\section{$N$ uptake and $N$ concentration of seed}

The interaction effect of bacteria $\times$ cultivar on seed $\mathrm{N}$ concentration was significant $(P<0.01)$ (Table 6). A comparison of the mean interaction effect of bacteria $\times$ cultivar on seed N concentration showed that in the Dasht cultivar, only strain S8 had significant superiority compared to control (14.2\%) and other strains demonstrated no significant superiority. Nevertheless, in the Sahra cultivar, strain S8 showed no significant superiority when compared to control, while other strains showed superiority when compared to control and the highest seed $\mathrm{N}$ concentration was obtained by $\mathrm{S} 4$ strain (28.7\%) (Figure 5).
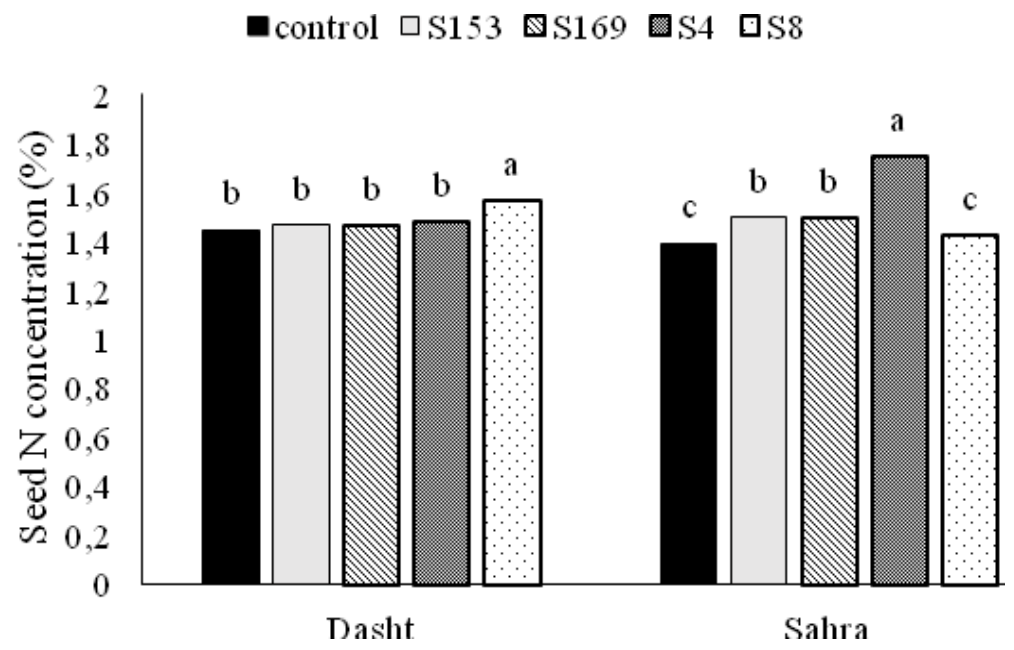

Figure 5. Interaction effect of barley cultivars $\times$ Pseudomonas strains on seed $N$ concentration. Means in each column followed by at least one similar letter are not significantly different at $5 \%$ probability level, using LSD test

The results of the analysis of variance showed that the interaction effect of Pseudomonas $\times$ AMF $\times$ barley cultivars $\times$ year on seed $\mathrm{N}$ uptake was significant $(P<0.05)$ (Table 6$)$. A comparison of the mean interaction effect of Pseudomonas $\times$ AMF $\times$ barley cultivars $\times$ year on seed nitrogen uptake showed that in the first year in the Dasht cultivar at the AMF non-use conditions, strains of Pseudomonas exhibited significant superiority compared to control and S4 strain $(20.19 \mathrm{~kg} / \mathrm{ha})$ demonstrated the 
highest nitrogen uptake, but in AMF use conditions, there was no significant difference between Pseudomonas strains. In the Sahra cultivar, in both AMF use and non-use conditions, strains of Pseudomonas exhibited significant superiority compared to control (8-49\% and 2-40\% under AMF use and non-use conditions, respectively, in comparison to control) and S4 strain (32.01 and $27.17 \mathrm{~kg} / \mathrm{ha}$ under AMF use and nonuse conditions, respectively) showed maximum nitrogen uptake (Table 7).

In the second year at Dasht cultivar in both AMF use and non-use conditions, strains of Pseudomonas exhibited significant superiority compared to control (22-65\% and 16$69 \%$ under AMF use and non-use conditions, respectively, in comparison to control). In the Sahra cultivar, at the AMF non-use conditions, S4 strain $(29.43 \mathrm{~kg} / \mathrm{ha})$ and in AMF use conditions, S8 strain $(27.65 \mathrm{~kg} / \mathrm{ha})$ exhibited the maximum seed nitrogen uptake. In total, the highest nitrogen uptake in both years was seen in Sahra cultivar and in strain S4, while in the first year, it was obtained in the AMF use conditions and in the second year, it was found in AMF non-use conditions (Table 7).

Given that this experiment was conducted at rainfed and water shortage conditions, it could be stated that the growth period has been increasingly reduced and plant has been faced with fewer opportunities for the accumulation of starch in the seed. Consequently, seed protein content is increased. In addition, according to many researchers, through participation in the building of RNA polymerase, zinc caused increase in amino acids and the synthesis of proteins (Koutroubas et al., 2016). As a result, it increased protein content as suggested by the high content of zinc in inoculated treatments in this experiment.

The seed nitrogen uptake that depends on seed nitrogen concentration and seed yield was more in most of co-inoculated treatments of AMF + Pseudomonas compared to plants merely inoculated with AMF or Pseudomonas. It seems that in stress conditions, AMF played an important role in the formation and stability of soil aggregate. Consequently, its improved soil hydrolytic conductivity led to the development of root system and improved water and nutrients uptake (Estrada-Campuzano et al., 2012).

In evaluating the interaction between Pseudomonas, Azotobacter and AMF on uptake of elements in sorghum, Sultana et al. (2016) stated that AMF inoculation alongside Pseudomonas increased the concentration of iron, zinc, copper, and protein, but increase in manganese content was not significant. They believed that the increased uptake of iron, zinc, copper, and protein was due to impact of the seed co-inoculation Pseudomonas + AMF in increasing cell division and elongation in roots and thus lateral root development in co-inoculation treatments of Pseudomonas + AMF. However, Haling et al. (2010) studied the root of millets in food and water shortage conditions. They reported that in poor and alkaline soils, when the ability of root in the production of organic acids in the root environment is higher and guides the rhizosphere toward acidification, it could lead to uptake of elements such as $\mathrm{N}$ and $\mathrm{P}$ thereby leading to increased plant growth. Therefore, microorganisms used in this study have the potential to produce organic acids and they could increase uptake of nutrients by reducing the $\mathrm{pH}$ of the soil. However, Nogueira et al. (2007) assessed the impact of AMF and some PGPRs on nutrient uptake in soybean and reported the role of AMF in $\mathrm{N}$ uptake as result of indirect symbiosis of AMF and plant. They believed that AMF increased the uptake of elements such as $\mathrm{P}, \mathrm{Fe}$ and $\mathrm{Mn}$ and it increased the uptake of nutrients by increasing the level of hyphae at the root surface, and this increase was independent from $\mathrm{N}$ uptake. In this experiment, the effect of inoculation in increasing the seed $\mathrm{N}$ in response to barley cultivar and year was different. 


\section{$P$ uptake and $P$ concentration of seed}

The results of the analysis of variance showed that the interaction effect of Pseudomonas $\times$ AMF $\times$ barley cultivars $\times$ year on $\mathrm{P}$ concentration was significant $(P<0.01)$ (Table 6). By comparing the mean interaction effect of Pseudomonas $\times$ AMF $\times$ cultivars $\times$ year on $\mathrm{P}$ concentration, it was found that in both years and in both cultivars, pseudomonas strains were significantly superior to control. In both years, S4 strain in most treatment combinations of AMF $\times$ cultivar had significant superiority compared to other strains. The important point is the impact of AMF on increasing the concentrations of seed $\mathrm{P}$ so that in most Pseudomonas treatments, using AMF increased seed $\mathrm{P}$ concentrations significantly (Table 7).

Table 6. Analysis of variance effect of barley cultivars under AMF and Pseudomonas inoculation on seed $N$ concentration, $N$ uptake, $P$ concentration and $P$ uptake

\begin{tabular}{|c|c|c|c|c|c|}
\hline \multirow[b]{2}{*}{ S.O.V } & \multirow[b]{2}{*}{ df } & \multicolumn{3}{|c|}{ Mean square } & \multirow[b]{2}{*}{$\begin{array}{c}\text { P uptake } \\
\text { (kg/ha) }\end{array}$} \\
\hline & & $\begin{array}{c}\text { Seed } \mathrm{N} \text { concentration } \\
(\%)\end{array}$ & $\begin{array}{c}\text { N uptake } \\
\text { (kg/ha) }\end{array}$ & $\begin{array}{l}\text { Seed } \mathrm{P} \text { concentration } \\
(\%)\end{array}$ & \\
\hline Y (Year) & 1 & $0.0520 \mathrm{~ns}$ & $235 * *$ & $0.142 * *$ & $28.1^{* *}$ \\
\hline Year / Rep & 4 & $0.0142 \mathrm{~ns}$ & $94.2 * *$ & $0.0014 \mathrm{~ns}$ & $0.086 \mathrm{~ns}$ \\
\hline Cultivar (C) & 1 & $0.020 \mathrm{~ns}$ & $406^{* *}$ & $0.069 * *$ & $18.71 * *$ \\
\hline AM fungi(M) & 1 & $0.019 \mathrm{~ns}$ & $31.41 *$ & $0.109 * *$ & $6.03 * *$ \\
\hline Bacteria (B) & 4 & $0.124 * *$ & $104.1 * *$ & $0.135 * *$ & $10.86^{* *}$ \\
\hline $\mathrm{Y} \times \mathrm{C}$ & 1 & $0.001 \mathrm{~ns}$ & $3.236 \mathrm{~ns}$ & $0.0005 \mathrm{~ns}$ & $0.421 *$ \\
\hline $\mathrm{Y} \times \mathrm{M}$ & 1 & $0.00007 \mathrm{~ns}$ & $6.25 \mathrm{~ns}$ & $0.006 \mathrm{~ns}$ & $0.000001 \mathrm{~ns}$ \\
\hline $\mathrm{Y} \times \mathrm{B}$ & 4 & $0.051 \mathrm{~ns}$ & $21.81^{*}$ & $0.115^{* *}$ & $0.070 \mathrm{~ns}$ \\
\hline $\mathrm{C} \times \mathrm{M}$ & 1 & $0.0001 \mathrm{~ns}$ & $0.137 \mathrm{~ns}$ & $0.0003 \mathrm{~ns}$ & $0.847 * *$ \\
\hline $\mathrm{C} \times \mathrm{B}$ & 4 & $0.137 * *$ & $15.19 \mathrm{~ns}$ & $0.004 \mathrm{~ns}$ & $0.510 * *$ \\
\hline $\mathrm{M} \times \mathrm{B}$ & 4 & $0.048 \mathrm{~ns}$ & $16.36 \mathrm{~ns}$ & $0.022^{*}$ & $0.757 * *$ \\
\hline $\mathrm{M} \times \mathrm{B} \times \mathrm{C}$ & 4 & $0.039 \mathrm{~ns}$ & $19.21 *$ & $0.0015 \mathrm{~ns}$ & $0.801 * *$ \\
\hline $\mathrm{Y} \times \mathrm{C} \times \mathrm{M}$ & 1 & $0.021 \mathrm{~ns}$ & $2.62 \mathrm{~ns}$ & $0.071 * *$ & $0.986^{* *}$ \\
\hline $\mathrm{Y} \times \mathrm{C} \times \mathrm{B}$ & 4 & $0.059 \mathrm{~ns}$ & $35.33 * *$ & $0.0015 \mathrm{~ns}$ & $0.080 \mathrm{~ns}$ \\
\hline $\mathrm{Y} \times \mathrm{M} \times \mathrm{B}$ & 4 & $0.021 \mathrm{~ns}$ & $19.71 *$ & $0.0020 \mathrm{~ns}$ & $0.764 * *$ \\
\hline $\mathrm{Y} \times \mathrm{C} \times \mathrm{M} \times \mathrm{B}$ & 4 & $0.035 \mathrm{~ns}$ & $38.57^{*}$ & $0.133 * *$ & $1.42 * *$ \\
\hline Error & 76 & 0.025 & 7.52 & 0.0037 & 0.082 \\
\hline $\mathrm{CV}(\%)$ & & 10.68 & 12.1 & 17.5 & 5.41 \\
\hline
\end{tabular}

*,** Significant at $P<0.05$ and $P<0.01$, respectively. $C V$ : Coefficient of Variation

The results of the analysis of variance showed that the interaction effect of Pseudomonas $\times$ AMF $\times$ barley cultivars $\times$ year on $\mathrm{P}$ uptake by seed was significant $(P<0.01)$ (Table 6). Comparing the interaction effect of Pseudomonas $\times$ AMF $\times$ cultivars $\times$ year on $\mathrm{P}$ uptake revealed that in both years and in each of the cultivars, pseudomonas treatments increased $\mathrm{P}$ uptake significantly in comparison to control. In the Dasht cultivar, in AMF use conditions, there was no significant difference between strains in the first year, but in the second year, this difference was significant and strain S8 showed the highest $\mathrm{P}$ uptake. AMF use in Dasht cultivar increased the difference between strains in both years so that in both cultivars, strain S8 had significant superiority when compared to other strains. In the Sahra cultivar, the process of phosphorus uptake was similar to Dasht cultivar, while in AMF non-use conditions in the second year, strain S4 showed the highest $\mathrm{P}$ uptake compared to other strains (Table 7). 
Table 7. Interaction effect of Pseudomonas strains $\times A M F \times$ Barley cultivars on biological yield, seed yield and harvest index

\begin{tabular}{|c|c|c|c|c|c|c|c|c|}
\hline \multirow{2}{*}{$\begin{array}{l}\text { Barley } \\
\text { cultivar }\end{array}$} & \multirow{2}{*}{$\mathrm{AMF}$} & \multirow{2}{*}{$\begin{array}{l}\text { Pseudomonas } \\
\text { strains }\end{array}$} & \multicolumn{2}{|c|}{$\mathrm{N}$ uptake $(\mathrm{kg} / \mathrm{ha})$} & \multicolumn{2}{|c|}{ Seed P concentration (\%) } & \multicolumn{2}{|c|}{ P uptake(kg/ha) } \\
\hline & & & Y1 & $\mathrm{Y} 2$ & $\mathrm{Y} 1$ & $\mathrm{Y} 2$ & $\mathrm{Y} 1$ & Y2 \\
\hline \multirow{5}{*}{ Dasht } & \multirow{5}{*}{ M0 } & Control & $17.22 \mathrm{~b}$ & $16.95 \mathrm{~d}$ & $0.283 b$ & $0.273 \mathrm{~d}$ & $2.83 \mathrm{~b}$ & $3.66 \mathrm{~d}$ \\
\hline & & S153 & $18.79 \mathrm{ab}$ & $19.78 \mathrm{c}$ & $0.373 \mathrm{a}$ & $0.326 \mathrm{~b}$ & $4.45 \mathrm{a}$ & $4.82 \mathrm{c}$ \\
\hline & & S169 & 19.38ab & $28.76 \mathrm{a}$ & $0.350 \mathrm{a}$ & $0.300 \mathrm{c}$ & $4.37 \mathrm{a}$ & $4.73 \mathrm{c}$ \\
\hline & & S4 & $20.19 a$ & $20.34 \mathrm{c}$ & $0.363 \mathrm{a}$ & $0.329 b$ & $4.55 \mathrm{a}$ & $5.35 \mathrm{~b}$ \\
\hline & & S8 & $18.22 \mathrm{ab}$ & $23.73 b$ & $0.340 \mathrm{a}$ & $0.366 \mathrm{a}$ & $4.17 \mathrm{a}$ & $6.34 \mathrm{a}$ \\
\hline \multirow{5}{*}{ Dasht } & \multirow{5}{*}{ M1 } & Control & $18.87 \mathrm{a}$ & $16.87 \mathrm{c}$ & $0.306 \mathrm{c}$ & $0.284 \mathrm{~d}$ & $3.40 \mathrm{~d}$ & $4.310 \mathrm{e}$ \\
\hline & & S153 & $19.92 \mathrm{a}$ & $22.01 \mathrm{~b}$ & $0.350 \mathrm{~b}$ & $0.362 b c$ & $4.27 \mathrm{c}$ & $5.746 c$ \\
\hline & & S169 & $21.50 \mathrm{a}$ & $26.66 \mathrm{a}$ & $0.350 \mathrm{~b}$ & $0.372 b$ & $4.27 \mathrm{c}$ & $6.772 \mathrm{~b}$ \\
\hline & & S4 & $20.81 \mathrm{a}$ & $27.95 \mathrm{a}$ & $0.436 \mathrm{a}$ & $0.393 \mathrm{a}$ & $5.74 \mathrm{a}$ & $7.137 \mathrm{a}$ \\
\hline & & S8 & $20.26 \mathrm{a}$ & $20.73 b$ & $0.373 b$ & $0.336 \mathrm{c}$ & $4.88 \mathrm{~b}$ & $4.940 \mathrm{~d}$ \\
\hline \multirow{5}{*}{ Sahra } & \multirow{5}{*}{ M0 } & Control & $19.35 d$ & $24.05 b$ & $0.286 \mathrm{c}$ & $0.289 \mathrm{c}$ & $3.98 \mathrm{~b}$ & $5.41 \mathrm{c}$ \\
\hline & & S153 & $24.07 \mathrm{~b}$ & $25.23 b$ & $0.383 \mathrm{a}$ & $0.350 \mathrm{ab}$ & $5.41 \mathrm{a}$ & $6.22 \mathrm{ab}$ \\
\hline & & S169 & $19.79 d$ & $25.28 \mathrm{~b}$ & $0.350 \mathrm{~b}$ & $0.340 \mathrm{~b}$ & $5.03 \mathrm{a}$ & $6.01 \mathrm{bc}$ \\
\hline & & S4 & $27.17 \mathrm{a}$ & $29.43 \mathrm{a}$ & $0.363 \mathrm{ab}$ & $0.376 \mathrm{a}$ & $5.28 \mathrm{a}$ & $6.67 \mathrm{a}$ \\
\hline & & S8 & $21.64 \mathrm{c}$ & $24.16 \mathrm{~b}$ & $0.343 b$ & $0.330 \mathrm{bc}$ & $5.14 \mathrm{a}$ & $5.69 \mathrm{bc}$ \\
\hline \multirow{5}{*}{ Sahra } & \multirow{5}{*}{ M1 } & Control & $21.37 \mathrm{c}$ & $21.34 \mathrm{c}$ & $0.316 \mathrm{~b}$ & $0.327 \mathrm{c}$ & $4.49 \mathrm{c}$ & $4.83 \mathrm{c}$ \\
\hline & & S153 & $19.54 d$ & $26.39 b$ & $0.376 \mathrm{a}$ & $0.369 b$ & $5.58 \mathrm{~b}$ & $6.36 \mathrm{ab}$ \\
\hline & & S169 & $24.40 \mathrm{~b}$ & 27.28ab & $0.390 \mathrm{a}$ & $0.354 \mathrm{~b}$ & $5.51 \mathrm{~b}$ & $6.19 b$ \\
\hline & & S4 & $32.01 \mathrm{a}$ & $26.51 \mathrm{~b}$ & $0.396 \mathrm{a}$ & $0.403 a$ & $6.19 a$ & $6.65 \mathrm{a}$ \\
\hline & & S8 & $23.23 b$ & $27.65 \mathrm{a}$ & $1491 b c$ & $0.358 \mathrm{~b}$ & $5.39 \mathrm{~b}$ & $6.46 \mathrm{ab}$ \\
\hline
\end{tabular}

Means within a column followed by the same letter are not significantly $(P<0.05)$ different according to LSD test. $(Y 1=2014-2015 ; Y 2=2015-2016)(M 0=A M F$ non-use; $M 1=A M F$ use $)$

Initial experiments on the strains of the bacterium used in this experiment show that Pseudomonas strains is able to dissolve the insoluble mineral $\mathrm{P}$ via the reduction of $\mathrm{pH}$ and it is able to produce and secrete acid and alkaline phosphatase enzymes and obtaining P from organic sources. Furthermore, efficiency of strain S4 in comparison with three other strains is higher in these characteristics. Therefore, it is obvious that the amount of P uptake and transport in strain S4 is higher and treatments inoculated had higher P content compared to control. Some believe that this increase in ionic content is related to the development of root systems and a general increase in the level of absorption of ions and is not associated with a specific mechanism (Guadarika et al., 2003). However, Kader et al. (2002) showed that bacterial inoculation affects ATPase and electrogenic pump in root cell membranes and by increasing leakage of protons from the root, it provides the driving force necessary to attract other ions for plant.

These microorganisms that have the ability to dissolve $\mathrm{P}$ mineral, and by secreting organic acids such as oxalic acid and citric acid, lead to the release of $\mathrm{P}$ into the soluble soil through chelating and the formation of stable complexes with iron, aluminum and calcium cations. In addition, 2-ketooxalic acid and glucuronic acid reduce the environment $\mathrm{pH}$ and soil insoluble phosphate solubilization by releasing protein (Salimpour et al., 2011). As a result of release of phosphorus in the soil, the root access to this element increases and the efficiency of $\mathrm{P}$ uptake in leaf increases. However, the type and amount of organic acids in any environment is related to the type of microorganisms producing the organic acid (Ghaderi et al., 2008). These results are in line with the results of the research conducted by Naseri et al. (2013). Saxena and Jha (2014) reported the greatest amount of P of wheat plant in relation to the co-inoculation of AMF + endophytic bacteria. The researchers reported the 
increased uptake of $\mathrm{P}$ by plants symbiosis with $\mathrm{P}$ solubilizing microorganisms due to the production of carbon by these microorganisms and its impact on increased ability in $\mathrm{P}$ uptake (Khan et al., 2013). Shaharoona et al. (2008) reported that $P$. fluorescents strain F increased absorption of $\mathrm{N}, \mathrm{P}$ and $\mathrm{K}$ compared to non-inoculated plants while reforming the growth elements of the wheat.

The findings of this study showed that phosphate-solubilizing microorganisms could increase growth and phosphorus uptake in the atmosphere, leading to increased crop tolerance under water deficit stress. In this experiment, increased phosphorus in aerial organs led to an increased seed phosphorous content such that maximum phosphorous was observed in the same strain. Therefore, we can say that any factor that increases phosphorous of aerial organs transports more phosphorus to seed, leading to an increased level of phosphorous content.

\section{Conclusion}

Given that this experiment was conducted in rainfed conditions, rainfall is the factor of change in seed yield and other physiological and biochemical reactions. In this experiment conducted in two consecutive years under rainfed conditions in Ardebil on barley cultivars under interaction between AMF and Pseudomonas strains, seed yield in both cultivars in the second year was higher due to more rainfall and effective dispersion (in terms of growth to plant barley). For this reason, reaction of cultivars inoculated treatments compared to first year was different. In both cultivars, maximum seed yield in both years was obtained from co-inoculation treatment of $\mathrm{AMF}+$ strain S4, while Sahra cultivar had more production sustainability compared to Dasht cultivar. While maximum seed yield in both cultivars was obtained from the same treatment, Sahra cultivar exhibited the better reaction to inoculation. The high seed yield in Sahra cultivar compared to Dasht cultivar can be attributed to reasons such as increased number of fertile tillers and number of seed per spike. Increase in the number of seed per spike and increase in fertile tiller can be due to proper nutrition and providing nutrients by AMF and Pseudomonas, since co-inoculation increased concentration of $\mathrm{N}$ and $\mathrm{P}$ significantly. However, the capability of AMF fungi in increasing uptake level that increases the uptake and retention of water in the rhizosphere plant should not be ignored. In addition, strains used in this experiment were associated with the production of the enzyme ACC deaminase and reduced levels of ethylene production (in rainfed conditions in which the plant is faced with water shortage and ethylene produced in the incidence of stress). Although in most of the characteristics measured, inoculated treatments were superior compared to control, the use of AMF also increased bacterial inoculation efficiency and by increasing the uptake of nutrients and increasing tolerance to water shortage conditions, it increased the seed yield, while this increase was more evident in the Sahra cultivar. Therefore, to plant barley in the rainfed conditions of Iran, Sahra cultivar alongside co-inoculation AMF and $P$. putida strain S4 is recommended. The development of drought-tolerant crop varieties through genetic engineering and plant breeding is essential but it is a long drawn process, whereas PGPR inoculation to alleviate drought stresses in plants opens a new chapter in the application of microorganisms in dry land agriculture. Taking the current leads available, concerted future research is needed in terms of identification of the right kind of microbes and barley cultivars and addressing the issue of delivery systems and field evaluation of potential organisms at diverse agro-ecological conditions under $\mathrm{N}$ and $\mathrm{P}$ fertilization. 


\section{REFERENCES}

[1] Abd_Allah, E. F., Hashem, A., Alqarawi, A. A., Hend, A. (2015): Alleviation of adverse impact of cadmium stress in sunflower (Helianthus annuus L.) by arbuscular mycorrhizal fungi. - Pak. J. Bot. 47: 785-795.

[2] Ahmad, P., Hashem, A., Abd-Allah, E. F., Alqarawi, A. A., John, R., Egamberdieva, D. (2015): Role of Trichoderma harzianum in mitigating $\mathrm{NaCl}$ stress in Indian mustard (Brassica juncea $\mathrm{L}$ ) through antioxidative defense system. - Frontiers in Plant Science 6: $1-15$.

[3] Ali, S., Hamza, M., Amin, G., Fayez, M., El-Tahan, M., Monib, M., Hegazi, N. (2005): Production of biofertilizers using baker's yeast effluent and their application to wheat and barley grown in north Sinai deserts. - Archives of Agronomy and Soil Science 51(6): 589-604.

[4] Alishahi, F., Alikhani, H. A., Heidari, A., Mohammadi, L. (2013): The study of inorganic insoluble phosphate solubilization and other plant growth promoting characteristics of indigenous Pseudomonas fluorescens bacteria of Kordan and Gonbad regions. International Journal of Agronomy and Agricultural Research 3: 53-60.

[5] Allahverdiyev, I. T., Javanshir, M. T., Huseynova, I. M., Aliyev, A. J. (2015): Effect of drought stress on some physiological parameters, yield, yield components of durum (Triticum durum desf.) and bread (Triticum aestivum L.) wheat genotypes. - Journal of Crop Breeding and Genetics 1: 50-62.

[6] Aroca, R., Ruiz-Lozano, J. M. (2009): Induction of plant tolerance to semi-arid environments by beneficial soil microorganisms-a review. - In: Climate change, intercropping, pest control and beneficial microorganisms (pp. 121-135). Springer Netherlands.

[7] Arshad, M., Shaharoona, B., Mahmood, T. (2008): Inoculation with Pseudomonas spp. containing ACC-Deaminase partially eliminates the effects of drought stress on growth, yield, and ripening of pea (Pisum sativum L.). - Pedosphere 18: 611-620.

[8] Arzanesh, M. H., Alikhani, H. A., Khavazi, K., Rahimian, H. A., Miransari, M. (2011): Wheat (Triticum aestivum L.) growth enhancement by Azospirillum sp. under drought stress. - World Journal of Microbiology and Biotechnology 27(2): 197-205.

[9] Asghar, H. N., Zahir, Z. A., Arshad, M., Khaliq, A. (2002): Relationship between in vitro production of auxins by rhizobacteria and their growth-promoting activities in Brassica juncea L. - Biology and Fertility of Soils 35:231-237.

[10] Bensalim, S., Nowak, J., Asiedu, S. K. (1998): A plant growth promoting rhizobacterium and temperature effects on performance of 18 clones of potato. - American Journal of Potato Research 75(3): 145-152.

[11] Cetin, O., Akinci, C. (2015): Effects of drought on optimizing nitrogen use of winter wheat in a semi-arid region. Agriculture and Forestry 61(1): 287-293.

[12] Chaurasia, B., Khare, P. K. (2005): Hordeum vulgare: A suitable substrate for mass production of arbuscular mycorrhizal fungi from natural soil. - Applied Ecology and Environmental Research 4:45-53.

[13] De Brito Alvarez, M., Gagné, S, Antoun, H. (1995): Effect of compost on rhizosphere microflora of the tomato and on the incidence of plant growth promoting rhizobacteria. Applied and Environmental Microbiology 61(1):194-199.

[14] Delshadi, S., Ebrahimi, M., Shirmohammadi, E. (2017): Influence of plant-growthpromoting bacteria on germination, growth and nutrients' uptake of Onobrychis sativa L. under drought stress. - Journal of Plant Interactions, 12(1), 200-208.

[15] Dijkman, T. J., Birkved, M., Saxe, H., Wenzel, H., Hauschild, M. Z. (2017): Environmental impacts of barley cultivation under current and future climatic conditions. - Journal of Cleaner Production 140: 644-653. 
[16] Egamberdieva, D., Adesemoye, A. O. (2016): Improvement of Crop Protection and Yield in Hostile Agroecological Conditions with PGPR-Based Biofertilizer Formulations. In Bioformulations: for Sustainable Agriculture (pp. 199-211). Springer India.

[17] Esfehani, J. Y., Khavazi, K., Ghorvani, S. (2009): Cross Interaction of Pseudomonas putida and Glomus intraradices and Its Effect on Wheat Root Colonization. - Pakistan journal of biological sciences 12(20): 1365-1370.

[18] Estrada-Campuzano, G., Slafer, G. A., Miralles, D. J. (2012): Differences in yield, biomass and their components between triticale and wheat grown under contrasting water and nitrogen environments. - Field Crops Research 128:167-179.

[19] Farajzadeh, D., Yakhchali, B., Aliasgharzad, N. Sokhandan-Bashir, N., Farajzadeh, M. (2012): Plant Growth Promoting Characterization of Indigenous Azotobacteria Isolated from Soils in Iran. - Current Microbiology 64 (4): 397-403.

[20] Frey-Klett, P., Garbaye, J., Tarkka, M. (2007): The Mycorrhiza helper bacteria revisited. - New phytologist 176(1): 22-36.

[21] Fröhlich, A., Buddrus-Schiemann, K., Durner, J., Hartmann, A., Von Rad, U. (2012): Response of barley to root colonization by Pseudomonas sp. DSMZ 13134 under laboratory, greenhouse, and field conditions. - Journal of Plant Interactions, 7(1), 1-9.

[22] Germida, J. J., Walley., F. L. (1996): Plant growth promoting rhizobacteria affect rooting patternand arbuscular mycorrhizal fungi colonization of field grown spring wheat. Biology and Fertility of Soils 23:113-120.

[23] Ghaderi, A., Aliasgharzad, N., Oustan, S., Olsson, P. A. (2008): Efficiency of three Pseudomonas isolates in releasing phosphate from an artificial variable charge mineral (iron III hydroxide). - Soil Environment 27: 71-76.

[24] Glick, B. R. (2014): Bacteria with ACC deaminase can promote plant growth and help to feed the world. - Microbiological research 169 (1): 30-39.

[25] Goldstein, A. (1986): Bacterial solubilization of mineral phosphates: historical perspective and future prospect. - American Journal of Alternative Agriculture 1(2): 5157.

[26] Gomez-Bellot, M. J., Nortes, P. A., Ortuno, M. F., Romero, C., Fernandez-García, C., Sanchez-Blanco, M. J. (2015): Influence of arbuscular mycorrhizal fungi and treated waste water on water relations and leaf structure alterations of Vibur numtinus L. plants during both saline and recovery periods. - Journal of Plant Physiology 188: 96-105.

[27] Habiba, U., Shaw, R., Takeuchi, Y. (2012): Farmer's perception and adaptation practices to cope with drought: Perspectives from Northwestern Bangladesh. - International Journal of Disaster Risk Reduction 1: 72-84.

[28] Haling, R. E., Richardson, A. E., Culvenor, R. A., Lambers, H., Simpson, R. J. (2010): Root morphology, root-hair development and rhizosheath formation on perennial grass seedlings is influenced by soil acidity. - Plant and Soil 335(1-2): 457-468.

[29] Heidari, M., Golpayegani, A. (2012): Effects of water stress and inoculation with plant growth promoting rhizobacteria (PGPR) on antioxidant status and photosynthetic pigments in basil (Ocimum basilicum L.). - Journal of the Saudi Society of Agricultural Sciences 11(1): 57-61.

[30] Jackson, M. L. (1962): Soil Chemical Analysis. - New York, NY: Prentice Hall.

[31] Kader, M. A., Mahn, M. H., Haque, M. S. (2002): Effects of Azotobacter inoculant on the yield and nitrogen uptake by wheat. - Online Journal of Biological Science 2: 259-261.

[32] Khalilzadeh, R., Seyed Sharifi, R., Jalilian, J. (2016): Antioxidant status and physiological responses of wheat (Triticum aestivum L.) to cycocel application and bio fertilizers under water limitation condition. - Journal of Plant Interactions 11(1): 130-137.

[33] Khan, M. S., Ahmad, E., Zaidi, A., Oves, M. (2013): Functional aspect of phosphatesolubilizing bacteria: importance in crop production. - In: Bacteria in Agrobiology: Crop Productivity (pp. 237-263). Springer Berlin Heidelberg. 
[34] Kheiri, M., Soufizadeh, S., Ghaffari, A. AghaAlikhani, M., Eskandari, A. (2017): Association between temperature and precipitation with dryland wheat yield in northwest of Iran. -Climatic Change 141(4): 703-717.

[35] Koutroubas, S. D., Fotiadis, S., Damalas, C. A. (2016): Grain yield and nitrogen dynamics of Mediterranean barley and triticale. - Archives of Agronomy and Soil Science 62(4): 484-501.

[36] Lingua, G., Bona, E., Manassero, P., Marsano, F., Todeschini, V., Cantamessa, S., Copetta, A., D’Agostino, G., Gamalero, E., Berta, G. (2013): Arbuscular mycorrhizal fungi and plant growth-promoting pseudomonads increases anthocyanin concentration in strawberry fruits (Fragaria $\times$ ananassa var Selva) in conditions of reduced fertilization. International journal of molecular sciences 14(8): 16207-16225.

[37] Lowry, O. H., Rosebrough, N. J., Farr, A. L., Randall, R. J. (1951): Protein measurement with Folin-phenol reagent. - Journal of Biology and Chemistry 193 (1): 265-275.

[38] Lu, H. D., Xue, J. Q., Guo, D. W. (2017): Efficacy of planting date adjustment as a cultivation strategy to cope with drought stress and increase rainfed maize yield and water-use efficiency. - Agricultural Water Management 179(1): 227-235.

[39] Malfanova, N., Kamilova, F., Validov, S., Shcherbakov, A., Chebotar, V., Tikhonovich, I., Lugtenberg, B. (2011): Characterization of Bacillus subtilis HC8, a novel plant-beneficial endophytic strain from giant hogweed. - Microbial biotechnology 4(4): 523-532.

[40] Mayak, S., Tirosh, T., Glick, B. R. (2004): Plant growth promoting bacteria that confer resistance to water stress in tomato and pepper. - Plant Science 166: 525-530.

[41] Mupangwa, W., Twomlow, S., Walker, S. (2012): Reduced tillage, mulching and rotational effects on maize (Zea mays L.), cowpea (Vigna unguiculata (Walp) L.) and sorghum (Sorghum bicolor L.(Moench)) yields under semi-arid conditions. - Field Crops Research 132: 139-148.

[42] Nadeem, S. M., Ahmad, M., Zahir, Z. A., Javaid, A., Ashraf, M. (2014): The role of mycorrhizae and plant growth promoting rhizobacteria (PGPR) in improving crop productivity under stressful environments. - Biotechnology advances 32(2): 429-448.

[43] Nadeem, S., Zahir, Z. A., Naveed, M., Arshad, M. (2007): Wheat lines in the presence of the plant growth promoting rhizobacterium Pseudomonas putida GR 12-2 and Azospirillum lipoferum DeK113. - Canadian journal of microbiology 53(10): 1141-1149.

[44] Naseri, R., Azadi, S., Rahimi, M. J., Maleki, A., Mirzaei, A. (2013): Effects of Inoculation with Azotobacter chroococcum and Pseudomonas putida on yield and some of the important agronomic traits in Barley (Hordeum vulgar L). - International Journal of Agronomy and Plant Production 4(7): 1602-1610.

[45] Navarro, J. M., Perez-Tornero, O., Morte, A. (2013): Alleviation of salt stress in citrus seedlings inoculated with arbuscular mycorrhizal fungi depends on the rootstock salt tolerance. - Journal of Plant Physiology 171(1): 76-85.

[46] Nogueira, M. A., Nehls, U., Hampp, R., Poralla, K., Cardoso, E. J. B. N. (2007): Mycorrhiza and soil bacteria influence extractable iron and manganese in soil and uptake by soybean. - Plant and Soil 298(1-2): 273-284.

[47] Oukarroum, A., Schansker, G., Strasser, R. J. (2009): Drought stress effects on photosystem I content and photosystem II thermotolerance analyzed using Chl a fluorescence kinetics in barley varieties differing in their drought tolerance. - Physiologia Plantarum 137(2): 188-199.

[48] Parmar, N., Dufresne, J. (2011): Beneficial interactions of plant growth promoting rhizosphere microorganisms. In Bioaugmentation, biostimulation and biocontrol (pp. 2742). Springer Berlin Heidelberg.

[49] Parry, M. A. J., Flexas, J., Medrano, H. (2005): Prospects for crop production under drought: research priorities and future directions. - Annals of Applied Biology 147(3): 211-226. 
[50] Penrose, D. M., Glick, B. R. (2003): Methods for isolating and characterizing ACC deaminase-containing plant growth promoting rhizobacteria. - Physiologia Plantarum 118(1): 10-15.

[51] Phillips, J. M., Hayman, D. S. (1970): Improvement Procedure for Cleaning and Staining Parasitic and Vesicular Arbuscular Mycorrhizal Fungi for Rapid Assessment of Infections. -Transactions of the British mycological Society, 55(1): 158-161.

[52] Prosdocimi, M., Jordán, A., Tarolli, P., Keesstra, S., Novara, A., Cerdà, A. (2016): The immediate effectiveness of barley straw mulch in reducing soil erodibility and surface runoff generation in Mediterranean vineyards. - Science of the Total Environment 547: 323-330.

[53] Ricken, B., Hofner, W. (2013): Effect of arbuscular mycorrhizal fungi (AMF) on heavy metal tolerance of alfalfa (Medicago sativa L.) and barley (Hordeum vulgare L.) on a sewage sludge treated soil. - Zeitschrift für Planzenernahrung und Bokenkunde 159: 189-194.

[54] Roesti, D., Gaur, R., Johri, B. N., Imfeld, G., Sharma, S., Kawaljeet, K., Aragno, M. (2006): Plant growth stage, fertilizer management and bio-inoculation of arbuscular mycorrhizal fungi and plant growth promoting rhizobacteria affect the rhizobacterial community structure in rain-fed wheat fields. - Soil Biology and Biochemistry 38(5): 1111-1120.

[55] Salimpour, S., Khavazi, K., Nadian, H., Besharati, H., Miransari, M. (2010): Enhancing phosphorous availability to canola (Brassica napus L.) using $\mathrm{P}$ solubilizing and sulfur oxidizing bacteria. - Australian Journal of Crop Science 4(5): 330-334.

[56] Sandhya V, Ali SKZ, Minakshi G, Gopal Reddy, Venkateswarlu B. (2009): Alleviation of drought stress effects in sunflower seedlings by the exopolysaccharides producing Pseudomonas putida strain GAP-P45. - Biology and Fertility of Soils 46(1):17-26.

[57] Saxena, J., Jha, A. (2014): Impact of a phosphate solubilizing bacterium and an arbuscular mycorrhizal fungus (Glomus etunicatum) on growth, yield and $\mathrm{P}$ concentration in wheat plants. - Clean-Soil, Air, Water 42(9): 1248-1252.

[58] Schalamuk, S., Velazquez, S., Chidichimo, H., Cabello, M. (2006): Fungal spore diversity of arbuscular mycorrhizal fungi associated with spring wheat: effects of tillage. - Mycologia. 98(1): 16-22.

[59] Schoppach, R., Soltani, A., Sinclair, T. R., Sadok, W. (2017): Yield comparison of simulated rainfed wheat and barley across Middle-East. -Agricultural Systems 153(1): 101-108.

[60] Schwyn, B., Neilands, J. (1987): Universal chemical assay for the detection and determination of siderophores. - Analytical biochemistry 160 (1): 47-56.

[61] Shaharoona, B., Naveed, M., Arshad, M. Zahir, A. (2008): Fertilizer-dependent efficiency of Pseudomonads for improving growth, yield, and nutrient use efficiency of wheat (Triticum aestivum L.). - Applied Microbiology and Biotechnology 79: 147-155.

[62] Sharma, S., Thind, H. S., Singh, Y., Singh, V., Singh, B. (2015): Soil enzyme activities with biomass ashes and phosphorus fertilization to rice-wheat cropping system in the Indo-Genetic plains of India. - Nutrient Cycling in Agroecosystems 101(3): 391-400.

[63] Sheffield, J., Wood, E. F., Roderick, M. L. (2012): Little change in global drought over the past 60 years. - Nature 491: 435-438.

[64] Shi Z. Y., Feng G., Christie P., Li, X. L. (2006): Arbuscular mycorrhizal status of spring ephemerals in the desert ecosystem of Junggar Basin China. - Mycorrhiza 16: 269-275.

[65] Sultana, U., Desai, S., Reddy, G. (2016): Successful colonization of roots and Plant growth promotion of sorghum (Sorghum bicolor L.) by seed treatment with Pseudomonas putida and Azotobacter chroococcum. - World Journal of Microbiology 3(1): 043-049.

[66] Tabatabaei, S., Ehsanzadeh, P., Etesami, H., Alikhani, H. A., Glick, B. R. (2016): Indole3 -acetic acid (IAA) producing Pseudomonas isolates inhibit seed germination and $\alpha$ amylase activity in durum wheat (Triticum turgidum L.). - Spanish Journal of Agricultural Research 14(1): 0802. 
[67] Vazquez M. M., Barea J. M., Azcon R. (2002): Influence of arbuscular mycorrhizae and a genetically modified strain of Sinorhizobium on growth, nitrate reductase activity and protein content in shoots and roots of Medicago sativa as affected by nitrogen concentrations. - Soil Biology and Biochemistry 34(7): 899-905.

[68] Vazquez, M. M., Cesar, S., Azcon, R., Barea, J. M. (2000): Interactions between arbuscular mycorrhizal fungi and other microbial inoculants (Azospirillum, Pseudomonas, Trichoderma) and their effects on microbial population enzyme activities in the rhizosphere of maize plants. - Applied Soil Ecology 15(3): 261-272.

[69] Vessey, J. K. (2003). Plant growth-promoting rhizobacteria as biofertilizers. - Plant and Soil 255(2): 571-586.

[70] Vílchez, J. I., García-Fontana, C., Román-Naranjo, D., González-López, J., Manzanera, M. (2016): Plant drought tolerance enhancement by trehalose production of desiccationtolerant microorganisms. - Frontiers in Microbiology 7: 1-12.

[71] Vurukonda, S. S. K. P., Vardharajula, S., Shrivastava, M., SkZ, A. (2016): Multifunctional Pseudomonas putida strain FBKV2 from arid rhizosphere soil and its growth promotional effects on maize under drought stress. - Rhizosphere 1: 4-13.

[72] Wagar, A., Shahroona, B., Zahir, Z. A., Arshad, M. (2004): Inoculation with ACC deaminase containing rhizobacteria for improvming growth and yield of wheat cultivars. - Pakistan Journal of Agriculture. 41(2): 119-124.

[73] Wu, Q. S., Ying-Ning, Z., Abd-Allah, E. F. (2014): Mycorrhizal Association and ROS in Plants. In: Oxidative Damage to Plants. (Ed.): Ahmad, P. DOI: http://dx.doi.org/ 10.1016/B978-0-12-799963-0.00015-0 @ 2014 Elsevier Inc. All rights reserved.

[74] Yang, J., Kloepper, J. W., Ryu, C. M. (2009): Rhizosphere bacteria help plants tolerate abiotic stress. Trends in plant science 14(1): 1-4.

[75] Zhang, B., Li, S., Chen, S., Ren, T., Yang, Z., Zhao, H., Han, X. (2016): Arbuscular mycorrhizal fungi regulate soil respiration and its response to precipitation change in a semiarid steppe. - Scientific reports, 6 . 